\title{
RESEARCH
}

Open Access

\section{Engineering failure analysis and design of support system for ancient Egyptian monuments in Valley of the Kings, Luxor, Egypt}

Sayed Hemeda ${ }^{1,2}$ (D)

\begin{abstract}
Background: The paper represents the first comprehensive experimental and numerical study for engineering failure analysis and appropriate design for the permanent mechanical support system for the tomb of the Sons of Ramesses II (KV5). It is, in fact, one of the largest rock cut tombs ever found in Egypt. During the late 18th Dynasty and throughout the19th, the tombs are usually located further down the Valley some distance from the rock walls. The builders often quarried through talus slopes, such as in the case of the tomb of Sons of Ramses II. It is clear that the tomb of sons of Ramsses II is much more susceptible to surcharge geostatic loading from the overburden rock strata, rock bursting, and structural damage of support pillars and walls induced to the water and past/recent flash floods impacts caused by heavy rain in the Valley. Since some of this tomb also makes contact with the underlying shale layers, that have the potential for swelling and shrinkage under changing moisture conditions. Expansive damages to these underground structures have been widely noticed in the Valley of the Kings. This tomb tends to be the worst preserved tomb in the Valley of the Kings. The Esna shale in the valley is particularly weak and unstable. It not only posed problems to the ancient quarryman, but to the modern conservator as well. When the shale comes into contact with moisture, it expands and can literally tear a hill side apart.

Results: The main adjectives of the geoenvironmental and geotechnical analyses carried out in the present study are to investigate the static stability, safety margins and engineering failure of the tomb of Sons of Ramsses II (KV5) under their present conditions, against unfavorable environmental (i.e. extensive weathering due to water and flash floods impact in the past and present), utter lack of preservation, geostatic overloading of structural rock support pillars, geotechnical and extreme seismic conditions. Also to design an appropriate geotechnical support system, according to the engineering rock mass classification, in particularly the rock mass rating RMR and quality rock tunneling index Q-system.




\begin{abstract}
(Continued from previous page)
Conclusions: The engineering analysis had been carried out through the following four steps: 1-Evaluation of the surrounding rocks (marl limestone) by experimental investigation and the Roclab program to obtain Hoek Brown Classification criterion, Mohr- Coulomb fit and the rock mass parameters in particular the global strength and deformation modulus. 2- Qualitative and quantitative estimations of relevant factors affecting the stability of the tomb in particularly the overburden or geostatic and dynamic loading. 3- 2D and 3D integrated geotechnical modeling of the tomb environment for stress, displacement analyses and determination of volumetric strains and plastic points using advanced codes and programs like Examine 2D and PLAXIS 3D. The numerical analysis results indicated that the safety factor of the rock pillar structural supports is 1.37 and the overstress state is 1.28 MPa. 4-Remedial and retrofitting policies and techniques, static monitoring and control systems which are necessary for the strengthening and stability enhancement of the tomb, where the rock mass classification indicated the rock mass where the KV5 is excavated is poor rock, with RMR 39 and $\mathrm{Q}$ value 1.87 .

Based on the underground engineering stable equilibrium theory and rock mass classification, three support structure techniques are provided and detailed illustrated with the case of KV5 in this study.
\end{abstract}

Keywords: Geotechnical problems, Rock character, Support structure, Tomb of the sons of Ramses II, Valley of the kings

\section{Background}

Amongst the many monument types which exist all over the world, underground sites such as caves, tombs, crypts and catacombs can be singled out as a category which has its own particular set of "adversaries". These locations are to a certain extent "protected" by the earth or rock surrounding them; this is especially so when these sites remain sealed, or has only one small or partially blocked opening to the exterior. However, when an interred site is discovered and uncovered, its microclimate is disturbed and fluctuations in internal conditions commence. These variations become accentuated if the protective covering is removed either during excavation or later to create a new wider access to the site. This instability eventually leads to deterioration of the site and in particularly any decorations or paintings it may contain. Further deterioration is caused by other unrelated sources such as water seepage and occasionally also flooding like the tomb KV5 which under investigation, salt damage and the accumulation of dust, debris and other contaminants. The problems are common to all painted underground and semi-buried sites in the valley of kings at Luxor, Egypt.

It is important to say that in geological engineering, including in underground rock engineering and rock mechanics, lots of the hazards sources arise from geotechnical uncertainty or error. The sources of uncertainty can be classified as: (1) inalienable spatial and fleeting fluctuation; (2) estimation and observing blunders; (3) demonstrating vulnerability; (4) load and stresses vulnerability (Brown 2012). In geotechnical engineering it is perceived that stone disfigurement is imperative in deciding the advancement of characteristic structures and structural highlights. Numerous investigations and field work has been done to comprehend the fragile break procedures and systems. Quite a bit of this focused on the research center testing and the estimation of fragile crack limits (Deere and Varde 1990).

The Geotechnical instability problems and degradation phenomena of rock cut tombs in the Valley of the Kings (KV) is likely to be dominated by gravity fall and sliding on structural features, also other factors such as excessively high rock stress, creep effect, poor geotechnical properties of rock structures, weathering and /or swelling rock and flash floods caused by heavy rains in the Valley, vibrations and dynamic loading as well as utter lack of preservation become important and can be evaluated by means of a classification of rock quality. The Esna shale in the valley is particularly weak and unstable. It not only posed problems to the ancient quarryman, but to the modern conservator as well. When the shale comes into contact with moisture, it expands and can literally tear a hill side apart.

The tomb was robbed in antiquity. Since then, it has been hit by at least eleven flash floods caused by heavy rains in the Valley. These have completely filled the tomb with debris and seriously damaged its comprehensively decorated walls. From about 1960 to 1990, tour buses parked above the tomb; their vibrations caused serious damage to parts of the tomb near the roadway, as did a leaking sewer line installed over the entrance when the Valley of the Kings rest house was built.

In October and November of 1994, two flood events occurred in the Valley of Kings, sending a warning to all heritage managers. In both cases, a local desert rainstorm occurred in the vicinity of the Valley of Kings. Storm-water runoff and sediment entered the tomb of Sons of Ramsses II and other many o tombs and caused erosion of gully floors.

Current farming procedures have additionally added to the topographical traits of the Nile Valley bowl. Today, ground water levels have ascended here, and debilitate 


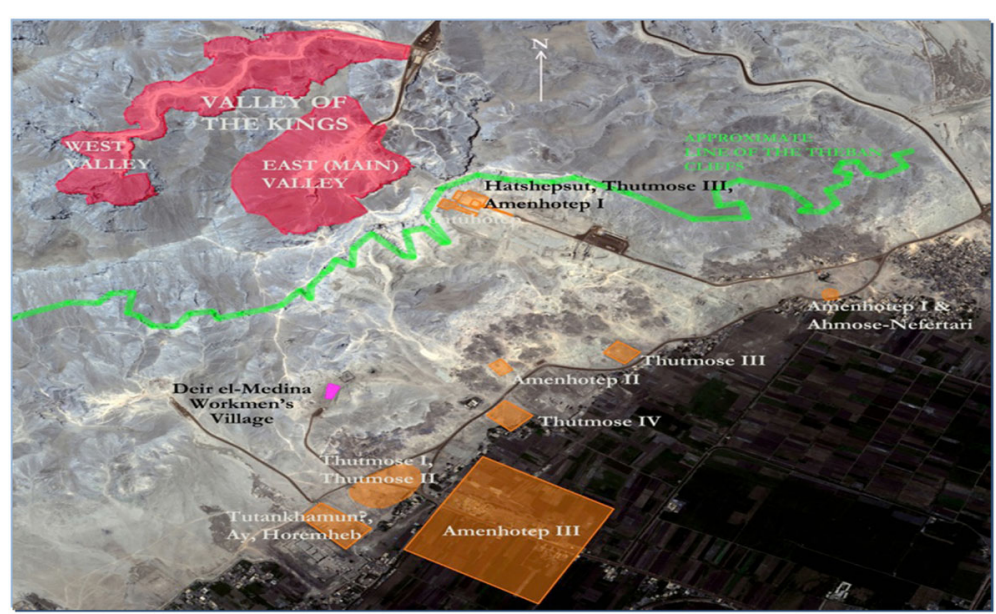

Fig. 1 Aerial photograph indicates the east (main) Valley of the Kings (KV) at Luxor Egypt. Modified after Google earth map. The tomb of Sons of Ramsses II (KV5) is located at the middle of the Valley of the Kings, East Valley, Thebes West Bank at Thebes. The Theban Mapping Project's excavations have shown that KV 5 contains not just the six rooms first seen by Burton in 1825, but over 150 corridors and chambers dug deep into the hillside

low lying shaft tombs and the morgue sanctuaries on the edge of the development, and in addition the outstanding Luxor and Karnak sanctuaries on the east bank.

The tomb of Sons of Ramsses II (KV5) is located at the middle of the Valley of the Kings, East Valley, Thebes West Bank at Thebes (Reeves and Wilkinson 1966). The Theban Mapping Project's excavations have shown that KV 5 contains not just the six rooms first seen by Burton in 1825, but over 150 corridors and chambers dug deep into the hillside, as shown in Fig. 1.

KV 5 itself is the largest rock cut tomb in the Valley of the Kings; pillared chamber 3 is the largest chamber of any tomb in the Valley of the Kings. Chambers 1 to 6 had been discovered in 1825 by James Burton, all other had been discovered by Theban Mapping Project in 1995 (Clayton 1995, Weeks 1992, 1994 and 1995), as shown in Fig. 2.

There is an adjustment in the tomb's essential pivot after chamber 3; a few chambers lie underneath different chambers; two hallways reach out toward the northwest underneath the passageway and the street before the tomb. Pillared chamber 3 has more columns (sixteen) than some other chamber in the Valley of the Kings. The measured dimensions of the KV5 are maximum height of $2.85 \mathrm{~m}$, width of $0.61 \sim 15.43 \mathrm{~m}$, total length of $443.2 \mathrm{~m}$; total area of $1266.47 \mathrm{~m}^{2}$ and total volume of $2154.82 \mathrm{~m}^{3}$. Pillars Conditions are excavated, decoration damaged, damaged structurally (Weeks 1998, 2000 and 2006), as shown in Fig. 3.

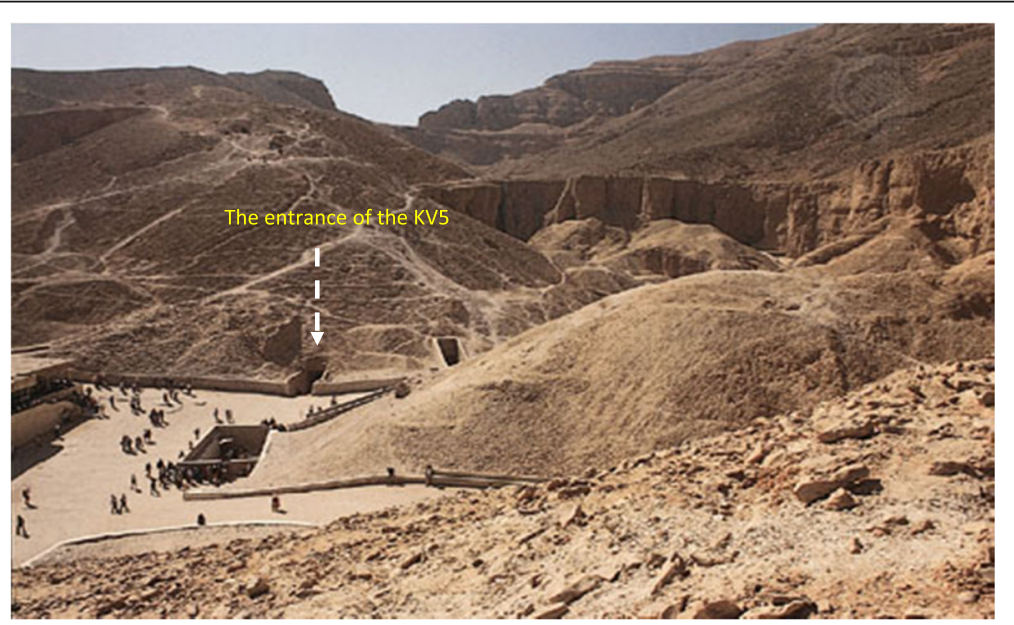

Fig. 2 Location of the tomb of Sons of Ramsses II (KV5) at the east (main) Valley of the Kings (KV), Luxor Egypt. KV 5 itself is the largest rock cut tomb in the Valley of the Kings; pillared chamber 3 is the largest chamber of any tomb in the Valley of the Kings. Chambers 1 to 6 had been discovered in 1825 by James Burton, all other had been discovered by Theban Mapping Project in 1995 (Clayton 1995) 


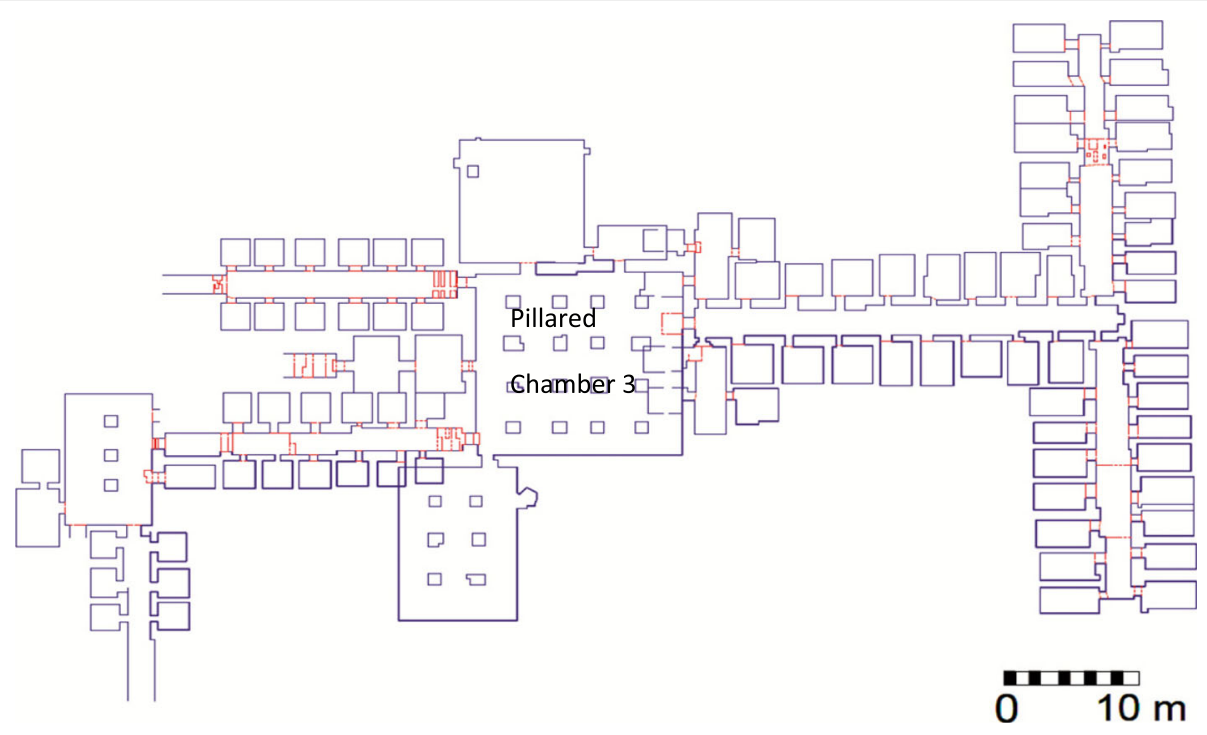

Fig. 3 The present layout and plan of the tomb of Sons of Ramsses II (KV5). The Measurements of the KV5 are: Maximum height: 2.85 m. Minimum width: $0.61 \mathrm{~m}$. Maximum width: $15.43 \mathrm{~m}$. Total length: $443.2 \mathrm{~m}$. Total area: $1266.47 \mathrm{~m}^{2}$. Total volume: $2154.82 \mathrm{~m}^{3}$. Pillars Conditions are excavated, cutting finished, decorated, decoration damaged, damaged structurally

\section{Methods and experimental}

The rock mass petrography and mechanical strength where the tomb of sons of Ramses II is excavated has been analyzed by experimental investigations, which include XRD, XRF and DTA-TGA analysis and thin section examination under polarized light microscope. A comprehensive program for petro physical and mechanical testing include the uniaxial compression test and ultra-sonic wave velocity through the materials (PUNDT) has been established. The RocLab program has been utilized to calculate the Hoek-Brown Classification and criterion also to calculate the Mohr-Coulomb fits and rock strength parameters in particularly the deformation modulus (RocLab 1.0. 2018). Underground structures safety analysis is performed using the finite element (FE) method. The research presents a comprehensive study for the rock cut tombs safety analysis. The safety analysis includes not only a failure analysis but the effect of weathering, in particular the materials wear on the differential settlement have been investigated. The commercial FE package Examine $2 \mathrm{D}$ is used for conducting stress, as well as settlement analysis. Examine 2D is a finite element program developed for numerical analysis of geotechnical and underground and subterranean structures (Examine 2D 2018).

The deformation of these rock cut tombs has been computed as realistically as possible, utilizing an advanced nonlinear elasto-plastic material model needs to be utilized in PLAXIS 3D which is capable of utilizing such advanced material models (PLAXIS 3D Software 2018). 3D Plastic model is used for deformation and consolidation analysis in this research. The consolidation analysis is performed using PLAXIS 3D. Also in this research, we attempt to construct and analyze a three-dimensional (3D) finite element model (FEM) of the pillared chamber 3 with its structurally damaged sixteen rock pillars and the large northern hall which are excavated in this poor and extensively weathered marl limestone deposit (member 1), using the PLAXIS 3D code.

The Rock Mass Classification calculations are utilized for the general assessment of the rock mass where the KV5 is excavated. The results of the rock mas rating (RMR) and Q-system values were utilized to design an appropriate support system.

\section{The geology of Gebel El-Gurnah, Luxor}

Gebel El-Gurnah is located some $4 \mathrm{~km}$ to the west of the River Nile, opposite to Luxor. The main exposed rock units in Gebel El-Gurnah are the Esna Shale and Thebes limestone formations. The tombs of the kings were excavated in the Thebes formations at northern side of Gebel El-Gurnah and the tombs of the queens were excavated at the southern side (Litherland 2013, Dunn 2014, Wüst and McLane 2000).

The main exposed rocks in Gebel El-Gurnah are the Esna Shale (late Paleocene- Early Eocene) and the conformatably overlying Thebes formation (Early Eocene).

\section{Esna Shale}

The lower $25 \mathrm{~m}$ of this formation is less calcareous, usually is green dark grey, and sometimes nearly block. The upper shale is whitish grey and greenish, more compact and carries more gypsum vienlets. The iron oxides vary in color. Brownish red and yellow hematitic and limonitic concretions are present; the ferruginous concretions 
are characteristic feature foe the whole formation. The gypsum vienlets run mostly parallel to the bedding planes (Wüst and McLane 2000), as shown in Fig. 4a.

\section{Thebes formation}

The Thebes formation exposed in the valley of kings could be subdivided into three members (from base to top) Hamadat, Beida and Al-Geer members however, the Thebes formation conformably overlying the Esna Shale. The lower member Hamadat is white, chalky indurated limestone with flint concretions, the middle member Beida is made up indurated, thick bedded, nodular limestone with flint bands extending parallel to the bedding planes, the uppermost member Al-Geer consists mainly of white limestone, (Aubry et al. 2008 and Siliotti 1997), as shown in Figs. $4 \mathrm{~b}$ and 5.

There are many faults in the SW corner of the Valley of the Kings; it is very composite in its nature. Number of faults are cutting the Eocene limestone Formations. Typically, those issue dividers bring differentiated throughout sliding, and veins about crystalline calcite have developed in the interceding spaces. The calcite may be stringy Furthermore structures overstepping bundles, which provide for the course What's more sense from claiming slip.

Ordinary faults, demonstrating level development for An NE-SW direction, are abundant. However, one substantial fault, on the Nw side of the valley, may be dominantly strike-slip (and left-lateral), while others need aid oblique-slip (left-normal, alternately right-normal). Despite those five faults that required been measured are not enough will a chance to be statistically significant, they are commonly perfect as shown in Figs. 6 and 7 . Figures 8 and 9 present the state of preservation of the KV5 and the geological and geotechnical induced rockmass stability problems. Where the brittle rock, high stress conditions lead to rockbursting (the sudden release of stored strain energy) bursts manifest themselves through sudden.

\section{Results of the experimental investigation}

Geotechnical properties of intact rock specimens and discontinuities

Twenty-three cylindrical rock specimens have been prepared from the surrounding rock and the supporting pillars to delineate the physical and mechanical properties. Specific gravity, unit weight, water absorption, porosity and degree of saturation are the physical aspects determined. While, the mechanical characterization included the determination of the uniaxial compressive strength, elastic static modulus of elasticity and Brazilian splitting tensile strength, as well as the Non-Destructive Ultrasonic Pulse Testing to the wave velocity through the brick specimens, the dynamic Young's modulus and shear modulus. All the soil/rock testing referring to the ASTM.

Thin-sections prepared on the limestone samples where the KV5 is excavated, refers that the limestone is fine-grained calcite, embedded in a micritic matrix rich in amorphous silica, fossils like Foraminifera and large grains of quartz.

The XRD analysis indicated that the major contents of Esna shale are quartz $\left(\mathrm{SiO}_{2}\right)$ and Montmorillonite $\left(\mathrm{Na}_{0.2}\right.$ $\mathrm{Ca}_{0.1} \mathrm{Al}_{2} \mathrm{Si}_{4} \mathrm{O}_{10}(\mathrm{OH})_{2} .\left(\mathrm{H}_{2} \mathrm{O}\right)_{10}$, the minor contents include the Kaolinite and Illite with Calcite traces. The bulk unit weight of the Esna shale is 1.79 to $1.86 \mathrm{~g} / \mathrm{cm}^{3}$, and the uniaxial compressive strength is 4.22 to $4.43 \mathrm{~kg} / \mathrm{cm}^{2}$.

Petro-physical properties: Physical measurements referred that the unit weight $(\gamma)$ of marl limestone of KV5 is between 20 and $21 \mathrm{kN} / \mathrm{m}^{3}$, water absorptions $(W a)$ were between 10 and $12 \%$ and the apparent porosity $(n)$ ranged from 14 to $19 \%$.
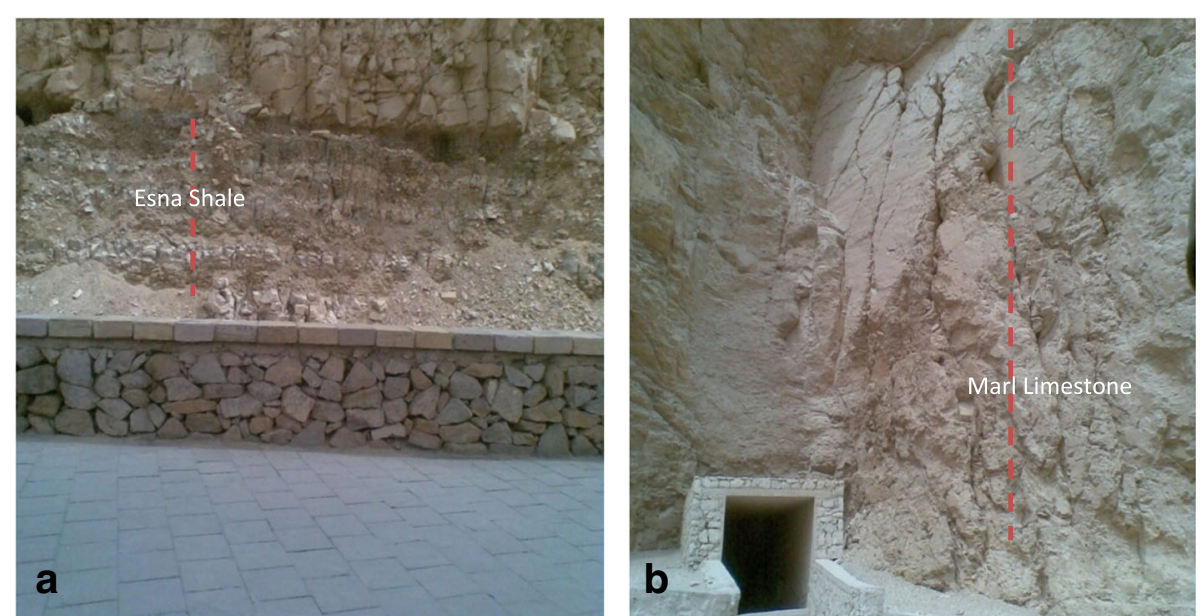

Fig. 4 a Esna Shale and b Marl Limestone (Member 1), Gebel El-Gurnah. The main exposed rocks in Gebel El-Gurnah are the Esna Shale (late Paleocene- Early Eocene) and the conformatably overlying Thebes formation (Early Eocene) 

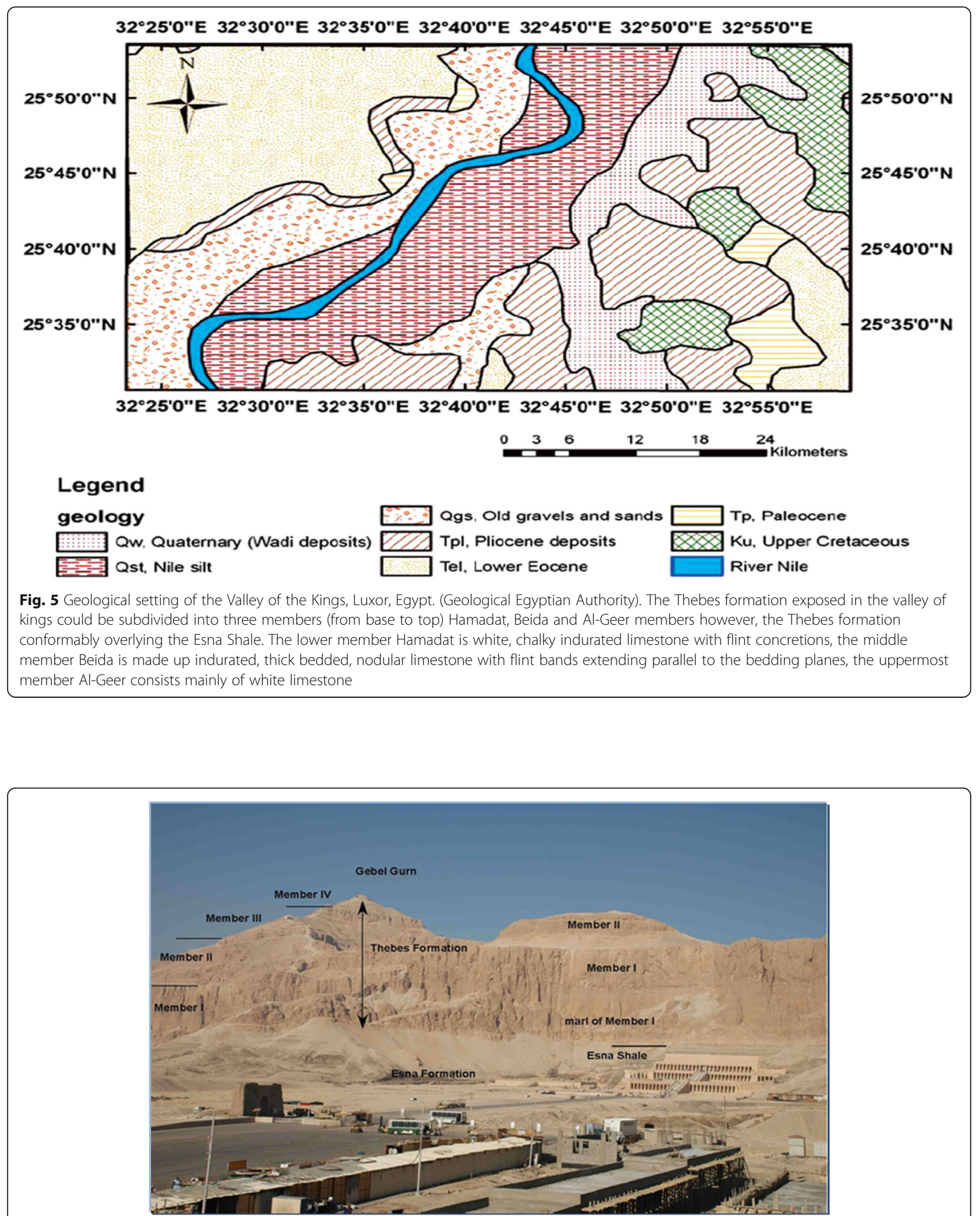

Fig. 6 Thebes Formations, Valley of the Kings, Luxor, Egypt. Gebel El-Gurnah is located some $4 \mathrm{~km}$ to the west of the River Nile, opposite to Luxor. The main exposed rock units in Gebel El-Gurnah are the Esna Shale and Thebes limestone formations. The tombs of the kings were excavated in the Thebes formations at northern side of Gebel El-Gurnah and the tombs of the queens were excavated at the southern side 


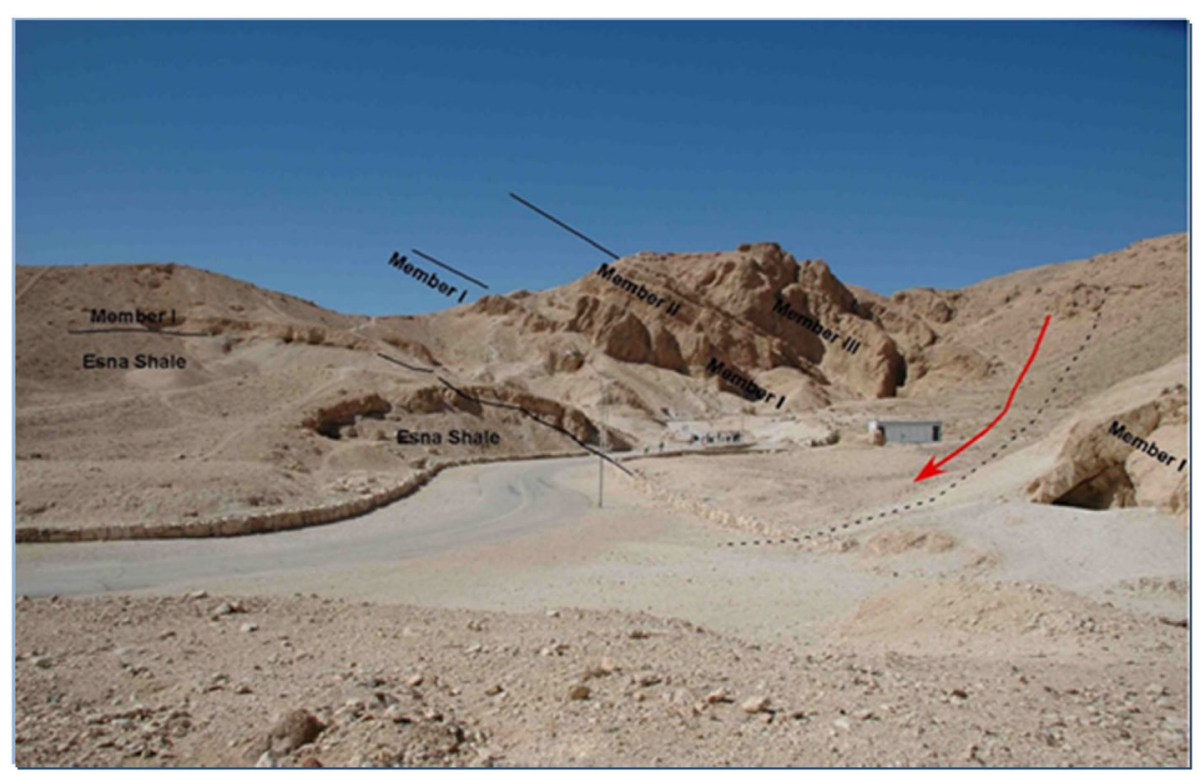

Fig. 7 Rock structures such as joints, bedding's characters of the Valley of the Kings (KV)

Shear Wave Velocities (Vs): Shear wave velocities of limestone samples were measured by PUNDT (ASTM 597, ASTM D 2845-83). They varied from 0.7 to $1.0 \mathrm{~km} / \mathrm{s}$ (with an average of $1 \mathrm{~km} / \mathrm{s}$ for an orientation perpendicular on the bedding plane.

Uniaxial Compression Test: The compressive strength $\left(\sigma_{c}\right)$ for the sidewalls is between 6 and $7 \mathrm{MPa}$, while the $\left(\sigma_{c}\right)$ for the supporting rock pillars is $1 \mathrm{MPa}$ because of the impact of the past and recent flash floods.
The static Young's modulus $(E)=10 \mathrm{GPa}$, Poisson Ratio $(v)=0.28-0.30$, Fig. 10 shows the test set and the results are summarized in Tables 1, 2, 3 and 4.

\section{Analysis of rock mass strength using RocLab program}

RocLab is a software program for determining rock mass strength parameters, based on the latest version of the generalized Hoek-Brown failure criterion.
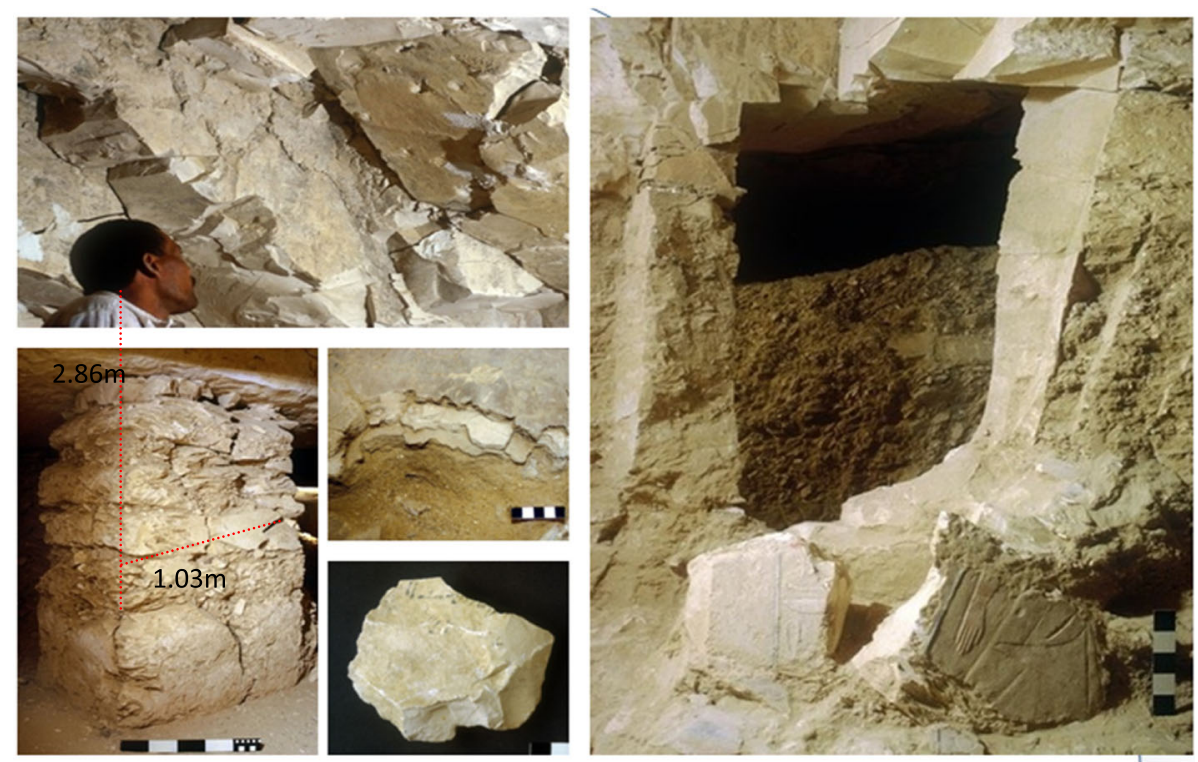

Fig. 8 Extensive structural damage in KV5. Engineering failure of the structural pillars, sidewalls and Ceiling of the Corridors and Chambers in the KV5 (http://www.thebanmappingproject.com/). Permission was granted by Weeks, K.R. ๑ Theban Mapping Project 2006 to reuse this figure 


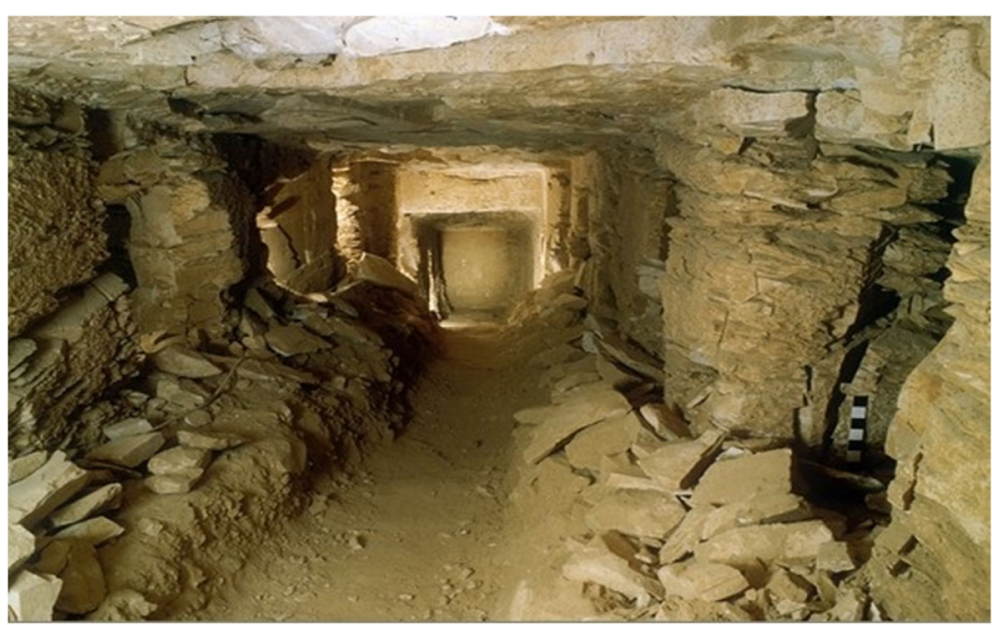

Fig. 9 Brittle rock, high stress conditions. Rockbursting (the sudden release of stored strain energy) bursts manifest themselves through sudden. (After TMP)

Hoek-Brown Classification: Intact uniaxial compressive strength of intact rock $\left(\sigma_{c i}\right)=7 \mathrm{Mpa}$, GSI geological structure index $=50$, intact modulus $(m i)=10$, disturbance factor $(D)=0$, intact rock deformation modulus $E i=3500 \mathrm{Mpa}$, modulus ratio $(M R)=500$.

The generalized Hoek-Brown Criterion failure criterion: $m b=1.677, s=0.0039 . a=0.506$, where $(\mathrm{s})$ and (a) are constants of the rock mass, calculated from the geological strength index (GSI) and disturbance factor (D).

Mohr-Coulomb Fit: Cohesion $c=0.349 \mathrm{Mpa}$, Friction angle $\phi=30^{\circ}$.

Rock mass parameters: Tensile strength of intact rock $\sigma_{t}=-0.016 \mathrm{Mpa}$, Uniaxial compressive strength, Figs. 11 and 12 .

\section{Results of the numerical analysis and geotechnical modeling \\ 2D static analysis}

In the initial 2D static analysis, the Sons of Ramses II tomb is modeled by assuming non-linear soil / rock plastic model and the Mohr-Coulomb failure criterion, (Hemeda and Pitlakis 2010), the 2D examine code is used for present study. The following parameters are used: $\phi=30^{\circ}, c=500 \mathrm{kN} / \mathrm{m}^{2}, E=10.100 \mathrm{E}+06 \mathrm{KN} / \mathrm{m}^{2}$, $\nu=0.3, \mathrm{Vs}=800 \mathrm{~m} / \mathrm{sec}$ for the rock material.

The results from the preliminary static analysis which are illustrated in Figs. 13, 14, 15, 16, 17, 18, 19 and 20 indicate that the maximum total displacements of the rock pillars in the large sixteen pillar chamber 3 were $1.2 \times 10^{-4} \mathrm{~m}$ and the vertical

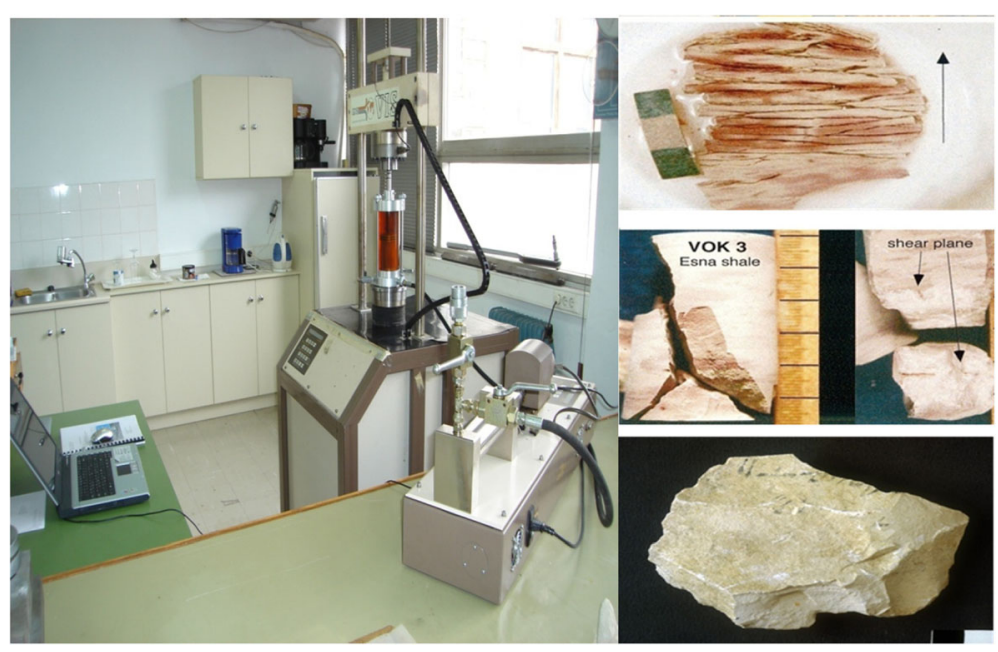

Fig. 10 Esna Shale and marl limestone samples under investigation 
Table 1 The geotechnical properties of the intact rock samples (KV5)

\begin{tabular}{|c|c|c|c|c|c|}
\hline No & $\mathrm{PI}(\mathrm{MPa}$ & oc (MPa) Sidewalls & oc (MPa) Pillars & Vs $(\mathrm{km} / \mathrm{s})$ & $\mathrm{RN}$ \\
\hline 1 & 0.4 & 7.1 & 0.9 & 0.7 & 18 \\
\hline 2 & 0.5 & 6.9 & 0.8 & 0.5 & 19 \\
\hline 3 & 0.4 & 7.5 & 0.95 & 0.8 & 20 \\
\hline 4 & 0.3 & 7.0 & 0.9 & 0.9 & 18 \\
\hline 5 & 0.5 & 6.9 & 0.8 & 0.7 & 17 \\
\hline 6 & 0.3 & 6.6 & 0.7 & 0.6 & 18 \\
\hline 7 & 0.4 & 7.0 & 1.1 & 0.7 & 19 \\
\hline
\end{tabular}

displacements were small (of the order of millimeters $1.5 \times 10^{-4} \mathrm{~m}$ ), Horizontal displacement $1.25 \times 10^{-5} \mathrm{~m}$, the maximum volumetric strain is $3.5 \times 10^{-5} \mathrm{~m}$, and the spalling criterion is 0.22 . While the maximum ground vertical displacements on the roof of the large western two halls were large $4.5 \times 10^{-5} \mathrm{~m}$ and the volumetric strain is $7 \times 10^{-6}$.

The rock pillars in the sixteen pillars largest hall (pillared chamber 3) are under relatively high compression stresses. The calculated effective peak principal compressive stresses on supporting rock pillars are about $900 \mathrm{kPa}$. The maximum shear stress is $0.15 \mathrm{MPa}$, and the maximum shear strain is $1.3 \times$ $10^{-5}$.

For the large northern hall, The calculated effective peak principal compressive stresses is about $600 \mathrm{kPa}$ but the maximum vertical displacement on the roof is too large $1.2 \times 10^{-4} \mathrm{~m}$ and the maximum volumetric strain is $4.5 \times 10^{-6}$, the results of the mathematical modeling are represented in Figs. 13, 14, 15, 16, 17, 18, 19 and 20. Also the maximum vertical stress on the roofs and sidewall of Chamber 1 and Chamber 2 reached $350 \mathrm{KPa}$, and the maximum vertical displacement reached $4.5 \times 10^{-5} \mathrm{~m}$, see Fig. 15, 16, 17, 18, 19 and 20.

\section{D static analysis}

The low rock strength where the KV5 is excavated affects seriously the safety of the tomb both under static and seismic loading conditions. The PLAXIS 3D was used for the 3-D numerical analysis of the central main

Table 2 The geotechnical properties of the intact rock samples with depth (KV5)

\begin{tabular}{llll}
\hline Depth & Weathering Grade & UCS (MPa) & E (MPa) \\
\hline $0-2 \mathrm{~m}$ & IV & $1-5$ & 2000 \\
$2-4 \mathrm{~m}$ & III & $5-10$ & 6000 \\
$4-6 \mathrm{~m}$ & II-III & $10-11$ & 10,000 \\
$6-8 \mathrm{~m}$ & III & $12-13$ & 10,000 \\
\hline
\end{tabular}

Table 3 Shear parameters of the discontinuities

\begin{tabular}{llll}
\hline Type & Peak Friction & Residual Friction & In-Situ \\
\hline Joints & $30^{\circ}$ & $30^{\circ}$ & JRC $(\mathrm{L}=1 \mathrm{~m})=3-4$ \\
Joints & $35^{\circ}$ & $25^{\circ}$ & $\mathrm{C}=30 \mathrm{kPa} \Phi=35^{\circ}$ \\
Joints & $35^{\circ}$ & $30^{\circ}$ & - \\
\hline
\end{tabular}

Chamber with its sixteen supporting structural rock pillars.

A three-dimensional (3D) numerical model for the pillared chamber 3 (the largest chamber in Valley of the Kings (with its sixteen supporting rock pillars) and the large northern hall which are excavated in marl limestone deposit are constructed. he goal of the 3D examinations is to assess the pressure state in the columns considering the 3D geometry. The $3 \mathrm{D}$ impacts issue is considered on a fundamental designing methodology in the consequent areas. The different reenactments depicted thus are directed utilizing the PLAXIS 3D code (PLAXIS 3D).

The results from the $3 \mathrm{D}$ static analysis which represented in Figs. 21, 22, 23 and 24 indicate that, the rock pillars in chamber 3 are under relatively high compression stresses. The calculated peak effective principal vertical compressive stresses on supporting rock pillars is $827.58 \mathrm{kN} / \mathrm{m}^{2}$, the horizontal effective mean stresses $588.91 \mathrm{kN} / \mathrm{m}^{2}$, the total displacement of the pillars $210.01 \times 10^{-6} \mathrm{~m}$, the vertical displacement $208.36 \times 10^{-6} \mathrm{~m}$, the horizontal displacement $32.94 \times 10^{-6} \mathrm{~m}$, the vertical incremental displacement $11.29 \times 10^{-6} \mathrm{~m}$, and the volumetric strain $3.62 \times 10^{-3} \%$.

For the large northern chamber, the extreme effective mean stresses is $567.73 \mathrm{kN} / \mathrm{m}^{2}$, the total displacement $475.95 \times 10^{-6} \mathrm{~m}$, the vertical displacement $475.59 \times 10^{-6} \mathrm{~m}$, the volumetric strain $12.42 \times 10^{-3} \%$, the extreme volumetric strain incremental $1.38 \times 10^{-3} \%$, and the horizontal displacement $53.60 \times 10^{-6} \mathrm{~m}$, Figs. 24, 25, 26, 27, 28 and 29. Also the maximum vertical stress on the roofs and sidewall of Chamber 1

Table 4 RMR value for the KV5 is determined as follow

\begin{tabular}{lll}
\hline Item & Value & Rating \\
\hline Uniaxial Compressive & $900 \mathrm{KPa}$ & 1 \\
Strength & 50 & 13 \\
RQD & $<60 \mathrm{~mm}$ & 5 \\
Spacing of Discontinuities & Separation 1-5 mm. & 10 \\
Conditions of & Continuous joints & \\
Discontinuities & Completely dry & 15 \\
Ground water & & -5 \\
$\begin{array}{l}\text { Adjustment for Joint } \\
\text { Orientation }\end{array}$ & & 39 Poor \\
Total RMR & & rock \\
\hline
\end{tabular}




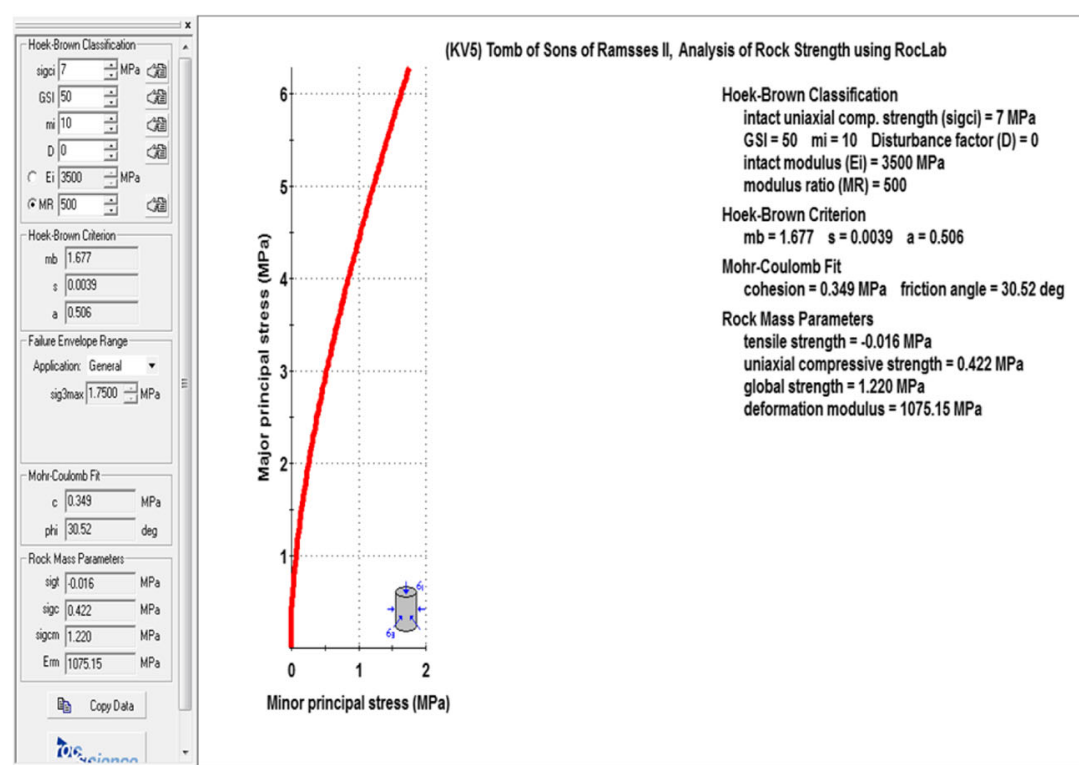

Fig. 11 Major and minor principal stress curve of marl limestone (KV5) using the RocLab program

and Chamber 2 reached $688 \mathrm{kPa}$, on the separate wall between them, the 2D model did not calculate it, and the maximum vertical displacement of the ceiling reached $0.18 \times 10^{-3} \mathrm{~m}$. as shown in Figs. 30, 31, 32 and 33 .

Figures 25 and 26 represent the analysis results of the large model which represents the complete east-west cross section of the tomb indicated that the stress distribution and displacement values on the structural rock pillars in the Chamber 3 and Chamber 1 and 2 did not increase due to the excavation process extended behind the sixteen pillared Chamber 3 may it is due to the lowering of the ceiling level of these small burial chambers. Figure 27 represents the displacement progressive curve for the supporting rock pillars.

\section{Evaluate the safety factor and stress state in the structural support pillars}

It is demonstrated that induced stresses of significant magnitude and ambiguous distribution are to be expected in the supporting pillars. Multiple openings and excavations designed on the basis of the average stress in the pillar $\sigma \mathrm{v}^{-}$given by the tributary area theory, as explained in Eq. 1.
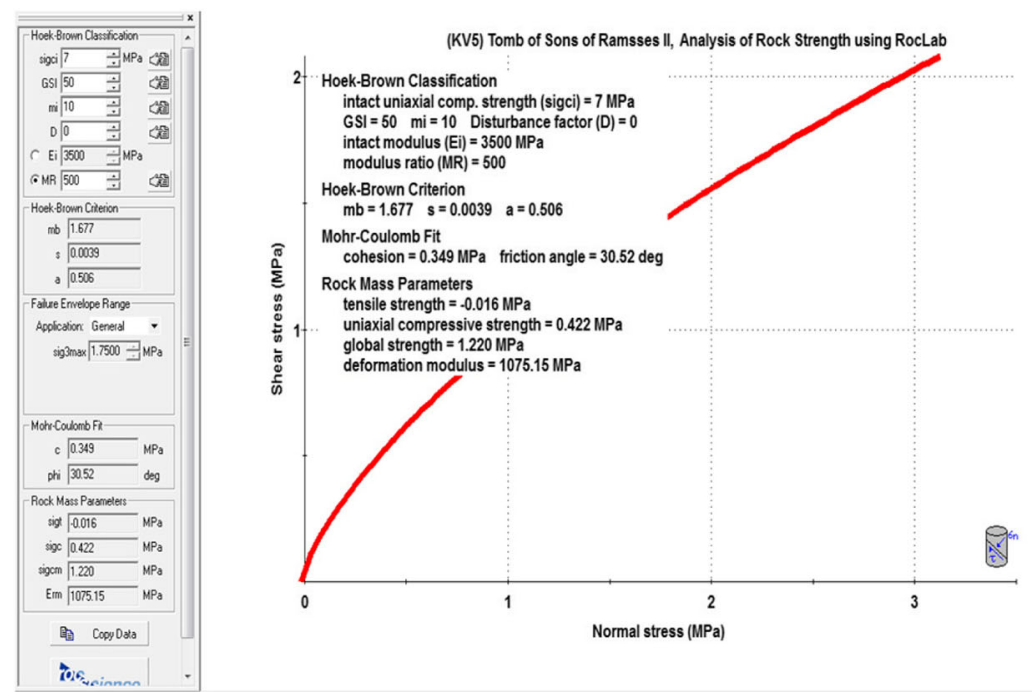

Fig. 12 Shear stress-Normal stress curve of Marl limestone (KV5), using the RocLab program 


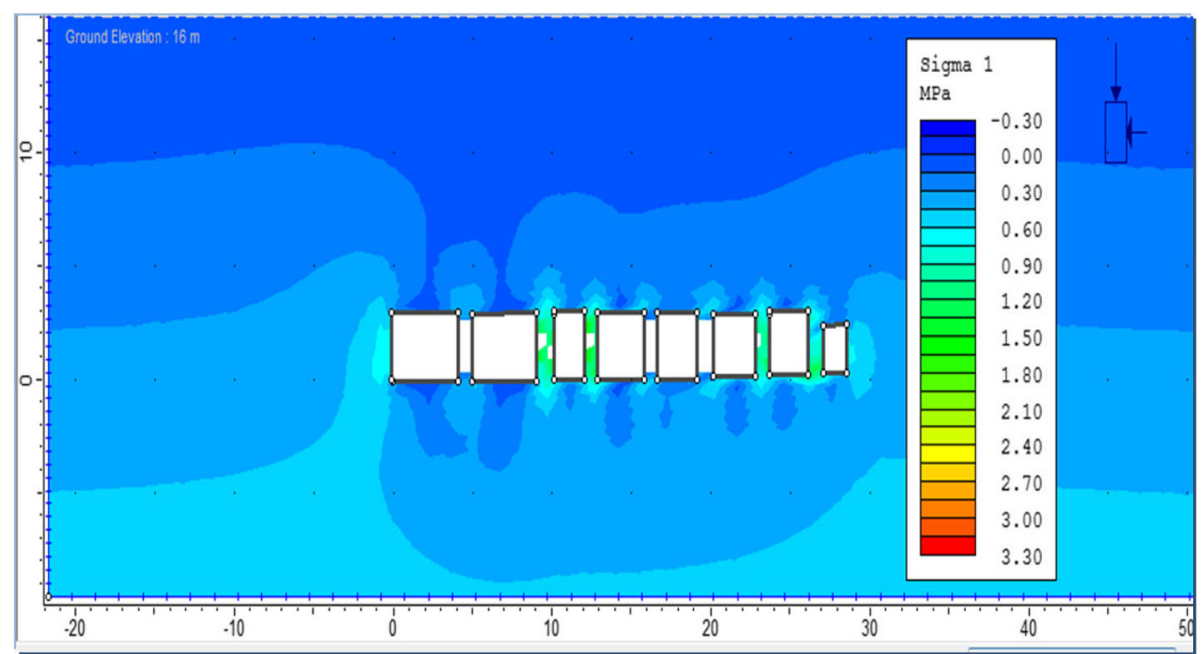

Fig. 13 Effective vertical stresses distribution through the rock pillars in Chamber 3. Examine 2D. All units of distance and depth in all figures are in meter

$$
\sigma v-=\frac{A t}{A P} \sigma v
$$

Where,

- $A_{t}$ is the area supported by the pillar

- $A_{p}$ is the area of the pillar

- $\sigma_{v}$ is the vertical stress at the level of the roof of the excavation (catacombs)

To evaluate the degree of safety of a pillar, we must be compare the above average pillar stress $\sigma_{v}$ with the pillar strength $\sigma_{\mathrm{p}}$. The latter is not simply the unconfined compressive strength of the material comprising the pillar $q_{u}$, because shape an $\delta$ size effects introduce significant modifications from the breaking strength of unconfined compressive cylinders.

The strength in compression for rectangular pillars of square cross section can be estimated from the Eq. 2 .

$$
\sigma_{\mathrm{p}}=\left\{0.875+0.250 \frac{W}{H}\right\}\left\{\frac{h}{h c r i}\right\}^{0.5}\left(\mathrm{q}_{\mathrm{u}}\right)
$$

Where,

- $\sigma_{\mathrm{p}}$ is the strength of the pillar,

- $-\mathrm{W}$ and $\mathrm{H}$ are the width and height of the pillar respectively,

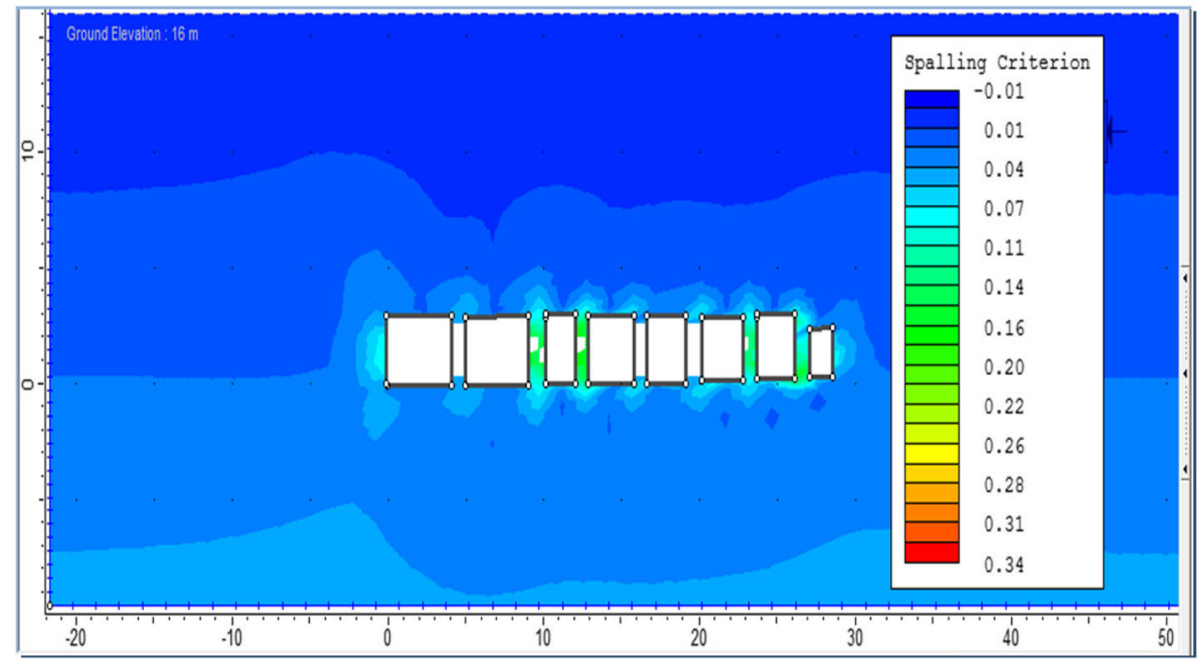

Fig. 14 Spalling Criterion through the rock pillars in Chamber 3. Examine 2D 


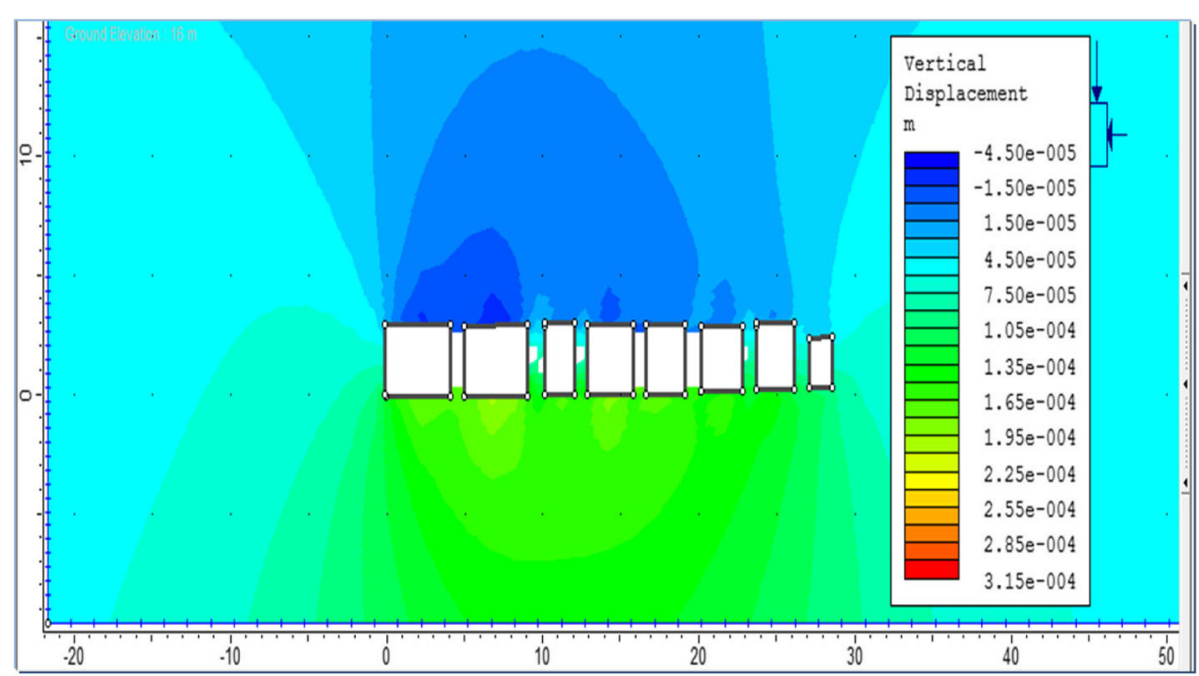

Fig. 15 Vertical displacement distribution through the rock pillars in Chamber 3. Examine 2D

- $\mathrm{q}_{\mathrm{u}}$ is the UCS strength of the pillar material on cylinders with height $(\mathrm{h})$ equal to twice the diameter and

- $\mathrm{h}_{\text {crit }}$ is the minimum height of the cubical specimen of pillar material such that an increase in the specimen dimension will produce no further reduction in strength.

For the pillars, see Fig. 21, $\sigma_{v}=700 \mathrm{Kpa}, \mathrm{A}_{\mathrm{t}}=2 \mathrm{~m}^{2}$ and $\mathrm{A}_{\mathrm{p}}=1 \mathrm{~m}^{2}$ we can derive:

$$
\sigma \mathrm{v}^{-}=\frac{2}{1} x 700=1400 \mathrm{KPa}
$$

The strength of the pillar $\sigma_{\mathrm{p}}$ can be estimated from the equation: For the pillar we have $\mathrm{W}=1 \mathrm{~m}, \mathrm{H}=3 \mathrm{~m}$. If we assume $h_{\text {crit }}=0.2 \mathrm{~m}$ and $\mathrm{h}=1 \mathrm{~m}$ for $\mathrm{q}_{\mathrm{u}}=900 \mathrm{Kpa}$, we have $\sigma_{\mathrm{p}}=1922 \mathrm{kPa}$.

And the Factor of Safety F.S $=\frac{\sigma p}{\sigma v-}=\frac{1922}{1400}=1.37$ which very low and indicate to the dangerous and unsafe situation and losing of the structural function of these load bearing pillars. Hoek and Bray quote Salamon and Munro's suggestion of acceptable safety factors $>1.6$. Such values may be adequate for the excavation stability, (Hemeda et al. 2010).

$$
\text { Also overstress state }=\frac{\sigma c}{\sigma v}=\frac{900 \mathrm{KPa}}{700 \mathrm{kPa}}=1.28 \mathrm{MPa}
$$

The tributary theory is based on average pillar stresses and derived stress value is generally close to

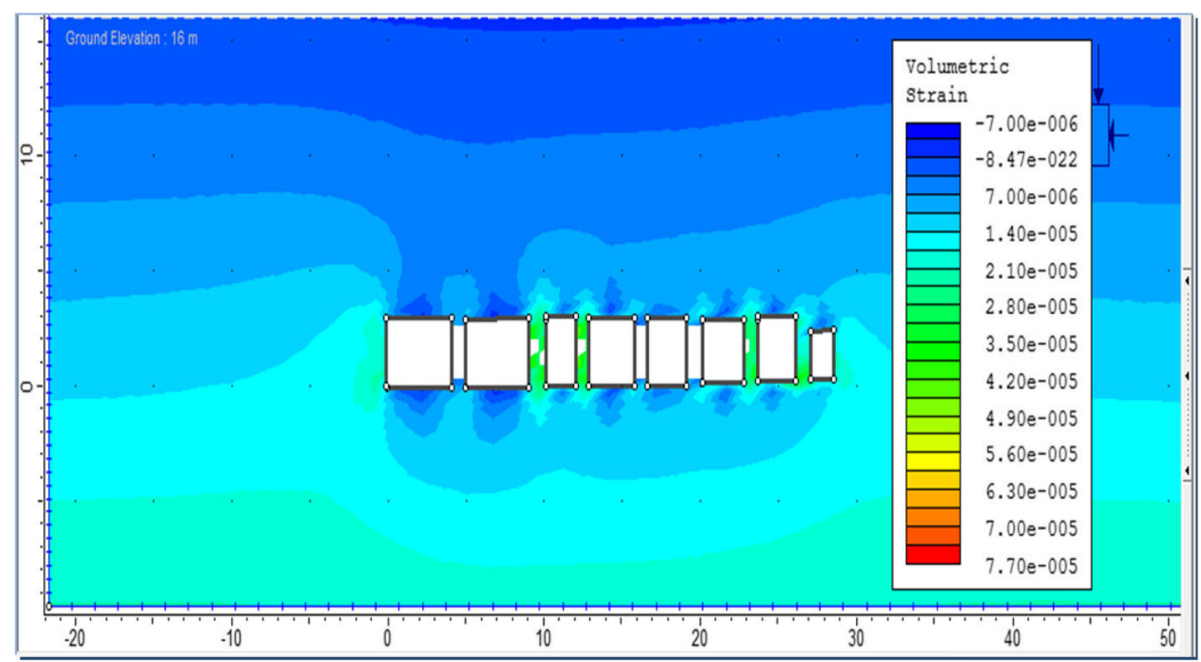

Fig. 16 Volumetric strain distribution through the rock pillars in Chamber 3. Examine 2D 


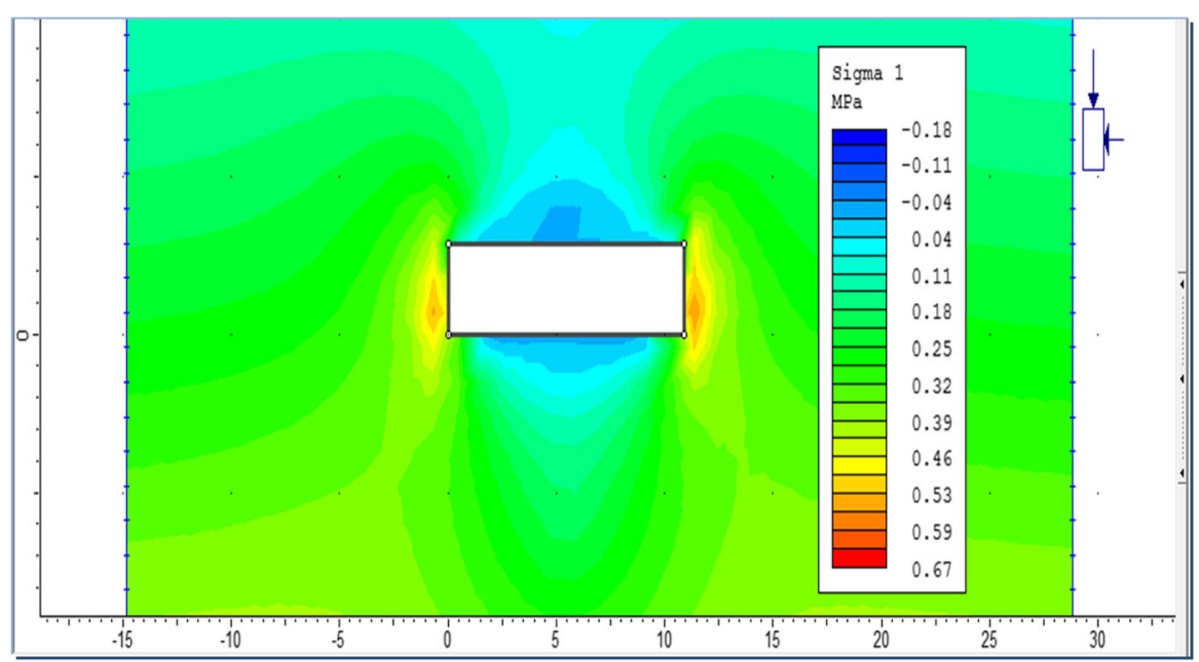

Fig. 17 Effective vertical stresses, the ceiling and sidewalls of northern Chamber. Examine 2D

the averages predicted by PLAXIS 3D.On other hand, the overloading of geostatic loading due to the overburden strata on the supporting rock pillars is obvious and it induced critical vertical cracks in these pillars also some sections have an overriding influence on the pillar stability, Eq. 3, particularly in terms of long-term creep effects and associated strength loss or thinning-out of the effective load bearing pillars and section, (Hemeda 2008). In the original study of Salamon and Munro this occurred between safety factors of 1.3 to 1.9 with the mean being 1.6. This value was recommended for the design of production pillars in South African bord and pillar workings (Salamon and Munro 1967).

\section{Design of structural supporting systems}

The first option, which depend on the RMR

Rock Mass Rating system is based on combination of six parameters $=$ Intact Rock Strength, RQD, Joint Spacing, Joint Conditions, Groundwater and Adjustment factor.

The first option depends on the Bieniawski's RMR (Bieniawski 1989) (Rock Mass Rating System) calculation, where the strength of intact rock is $900 \mathrm{kPa}$ (with rate 1), the RQD is 50 (with rate 13), the spacing of joints less than $60 \mathrm{~mm}$ (with rate 5), the conditions of discontinuities is Separation 1-5 $\mathrm{mm}$ with Continuous joints (with rate 10) and the ground water conditions are completely dry (with rate 15),

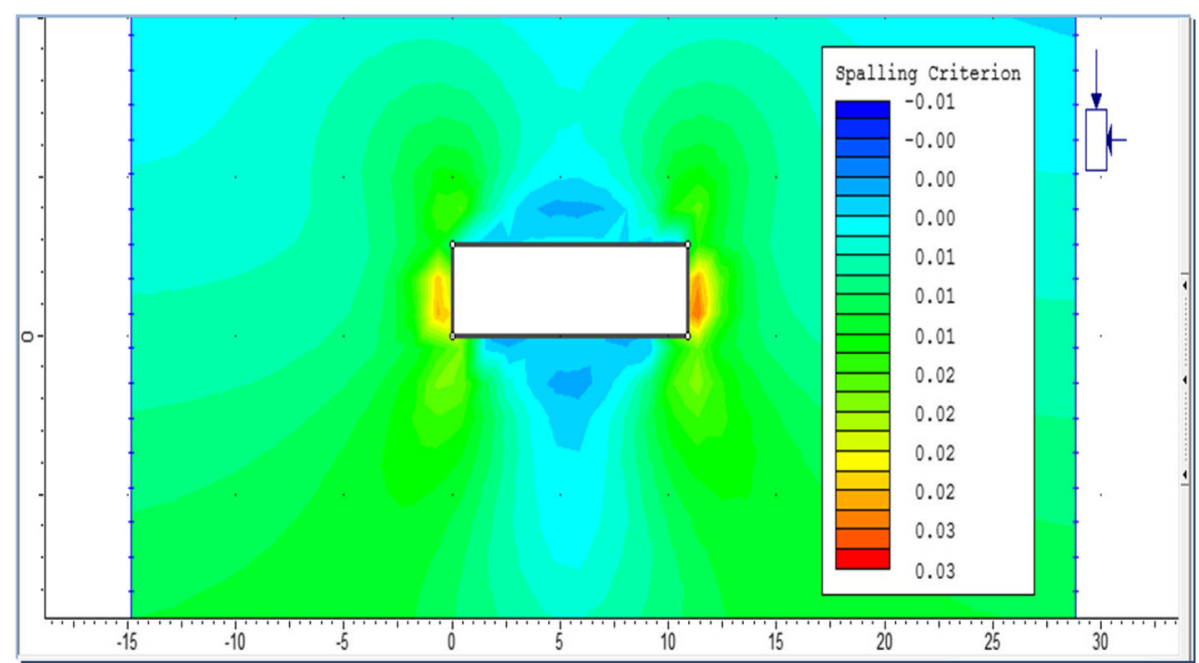

Fig. 18 Spalling Criterion for the ceiling and sidewalls of northern Chamber. Examine 2D 


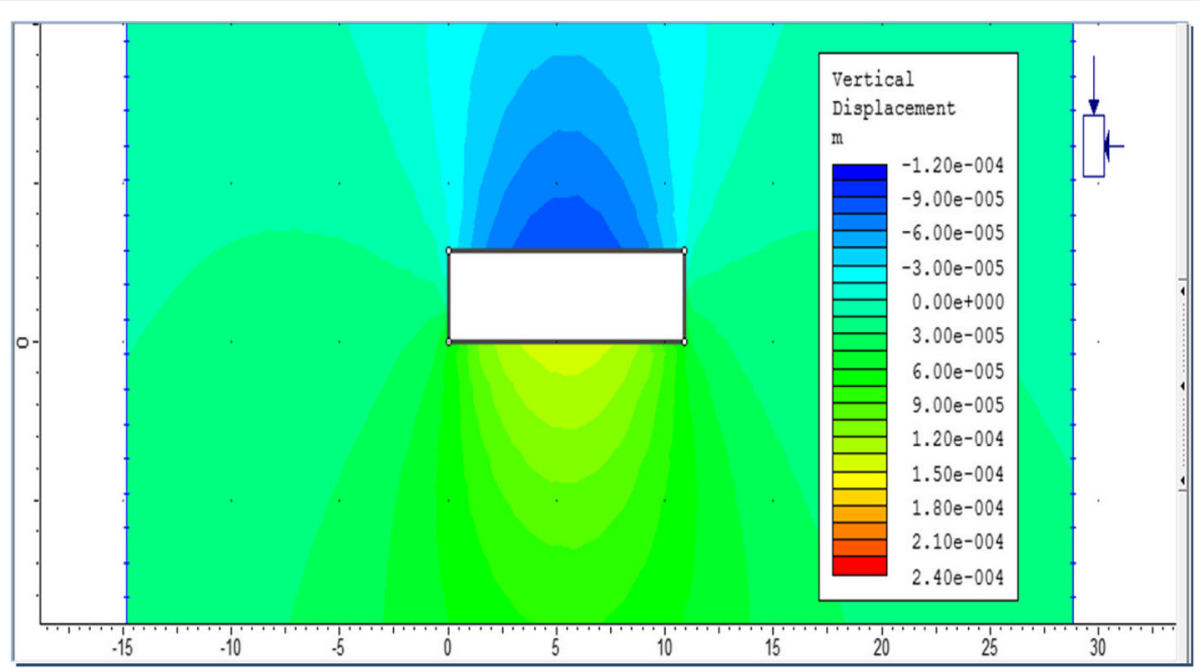

Fig. 19 Vertical displacement of the ceiling and sidewalls of northern Chamber. Examine 2D

for the adjustment for joint orientation is -5 then The RMR of the Sons of Ramses II tomb is (39) which classified as poor rock with high stresses, as shown in Table 4.

According to the RMR value, the design of the support system for the pillars and whole KV5 can include Systematic bolts 4-5 m long, spaced 1-1.5 $\mathrm{m}$ in Crown and walls with wiremesh.100-150 $\mathrm{mm}$ in Crown and100mm insides with Light to medium ribs Spaced $1.5 \mathrm{~m}$ where required.

\section{The second option, which depend on the Q-system}

The 2nd option depends on the Barton's Q-system or the rock tunneling quality index of the rock mass where the tomb is excavated.
The Q-system of Barton et al. (Barton et al. 1974, Barton 1988) expresses the quality of the rock mass in the so-called Q-value. The Q-value is determined as follows, Eq. 4:

From the Q-system parameters which include the RQD is 50 , Jn with value 4 , Jr. with value 3 , Ja with value 1 , Jw with value 1.

$$
\mathrm{Q}=\cdot \frac{R Q D}{J n} x \frac{J r}{J a} x \frac{J w}{S R F}
$$

For a depth below surface of $17 \mathrm{~m}$, the overburden stress will be approximately $17 \mathrm{~m}^{2}$ X $21 \mathrm{kN} / \mathrm{m}^{3}=396 \mathrm{kpa}$. The major principal stress $\sigma 1$ is $2 \times 396=792 \mathrm{kPa}$. Given the uniaxial compressive strength of the supporting rock pillars is approximate $900 \mathrm{KPa}$, this gives a ratio of $\frac{\sigma c}{\sigma 1}=\frac{900}{792}=$

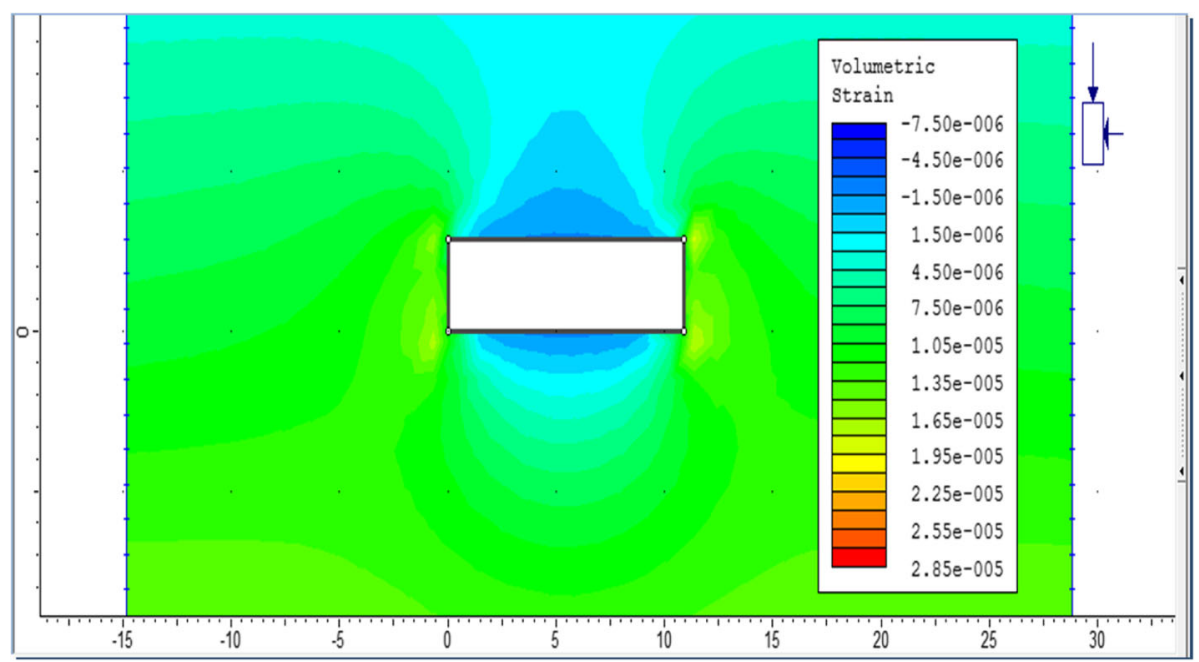

Fig. 20 Volumetric strains of the ceiling and sidewalls of northern Chamber. Examine 2D 


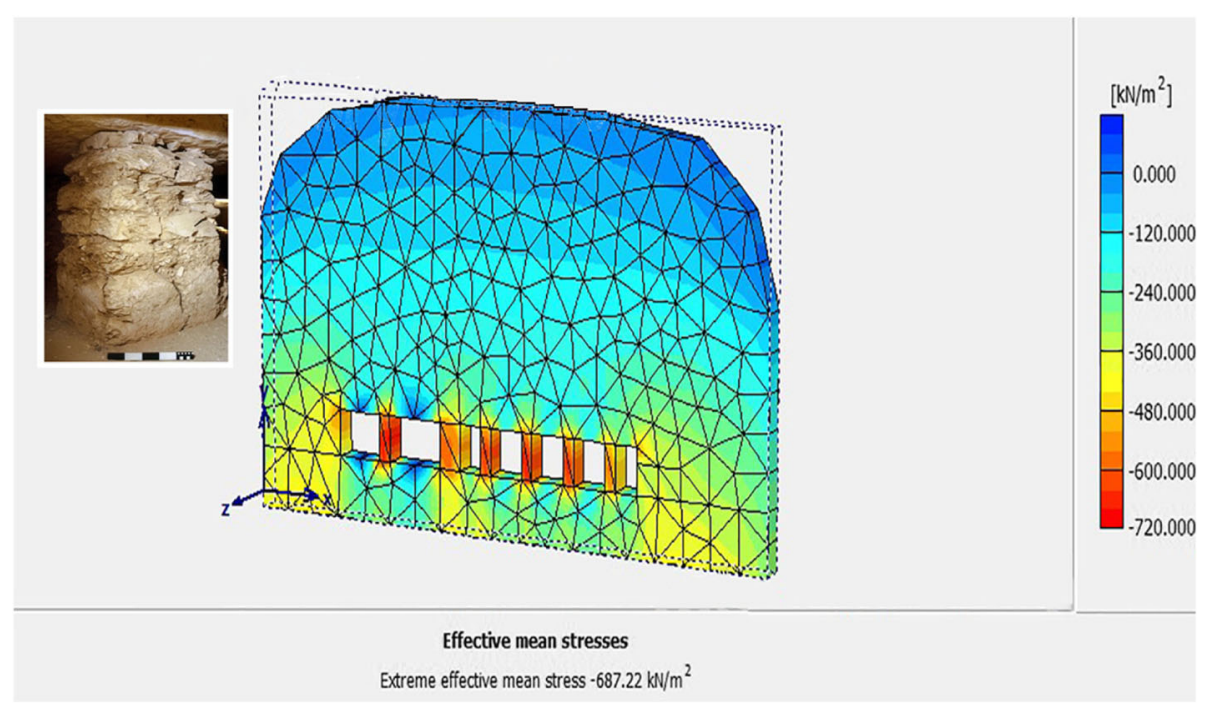

Fig. 21 Effective mean stresses distribution through the rock pillars in Chamber 3. PLAXIS 3D

$1.136<2.5$ which refer to a high stressed poor rock with SRF 20, then $\mathrm{Q}$ or rock mass quality value is 1.87 (poor rock according to the Q-system), as shown in Table 5.

For an excavation span (the width of the pillared chamber 3) of $15.6 \mathrm{~m}$, the equivalent diameter, $\mathrm{De}=$ $15.46 / 1.6=9.66$, where the ESR or the permanent opening is 1.6 and the width of the pillared chamber 3 is $15.46 \mathrm{~m}$.

The value of De of 9.66 and value of $\mathrm{Q}$ of 1.87 places the tomb of sons of Ramses II in category (5) which require Fiber Reinforced Shotcrete and bolting
5-9 $\mathrm{cm}$. Length of rockbolts with $\mathrm{L}=2+(0.15 \mathrm{~B} / \mathrm{ESR})$ and Maximum span (unsupported) $=2$ ESR X $\mathrm{Q}^{04}$ (Fig. 28). The strength properties of FRPs collectively make up one of the primary reasons for which select them in the strengthening and seismic retrofitting. A material's strength is governed by its ability to sustain a load without excessive deformation or failure. Also it is recommended to use the Carbon FRP also nowadays we can use the advanced or Nano CFRP because of its good mechanical properties in particularly the compressive and tensile strength.

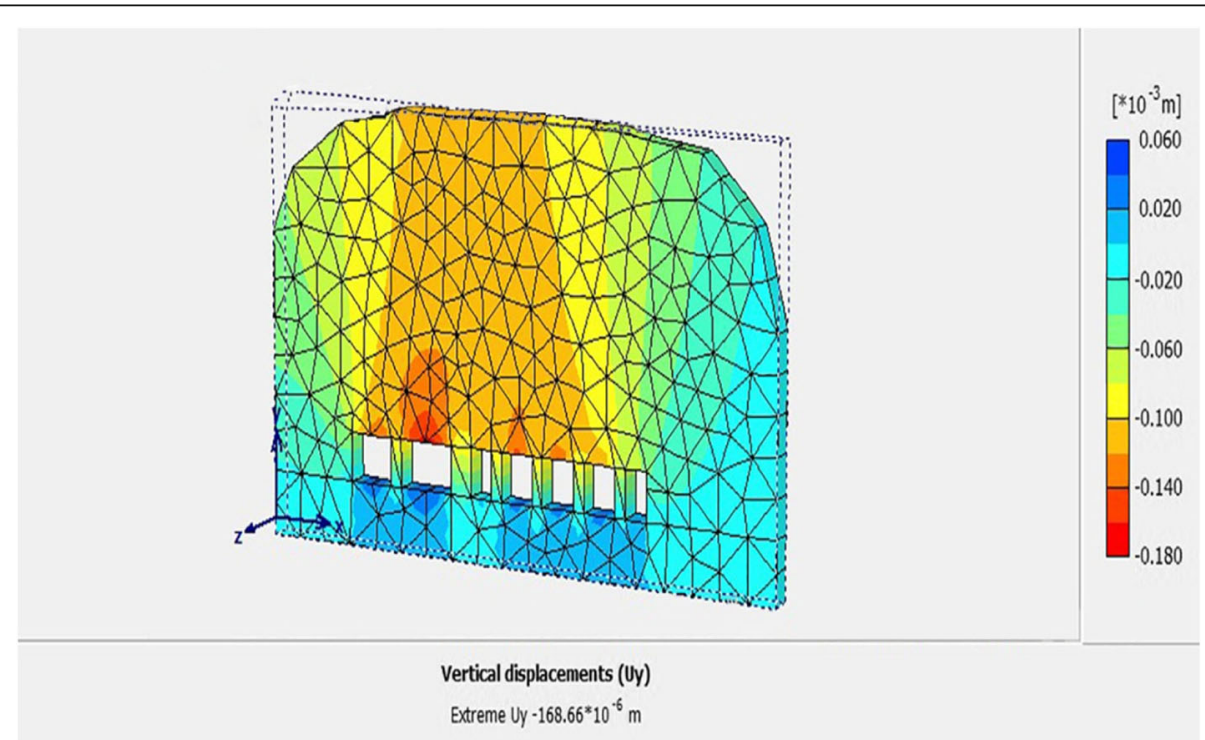

Fig. 22 Vertical displacements of the support rock pillars in Chamber 3. PLAXIS 3D 


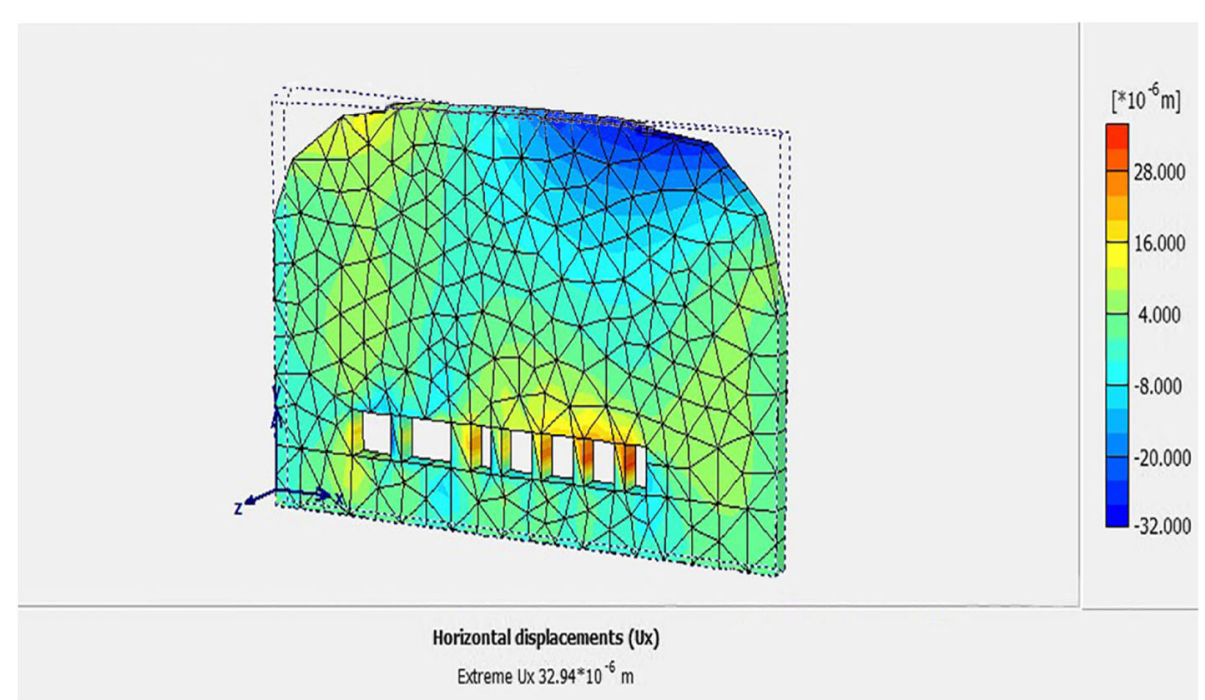

Fig. 23 Horizontal displacements of the support rock pillars in Chamber 3. PLAXIS 3D

\section{The third option}

The third option for the permanent support for this complex kind of underground structures could be designed as presented in Fig. 34, Where the rock bolts with 4-9 $\mathrm{cm}$ and prestressed anchors or micro piles with $100 \mathrm{~mm}$ Diameter for the permanent support system for the rock pillars and sidewalls of the KV5.

\section{Discussion of numerical, laboratory analysis results and the field observations}

The rock mass which the sons of Ramses II tomb is excavated can be classified as moderately to extensively jointed or fractured rock contains joints and hair cracks, but the blocks between joints are locally grown together or so intimately interlocked that vertical walls do not require lateral support. In rocks of this type, both spalling and popping conditions may be encountered.

It is notice that In brittle rock, high stress conditions may lead to rock bursting (the sudden release of stored strain energy) bursts manifest themselves through sudden, as shown in Fig. 9.

Analysis and interpretation of the numerical and laboratory results and the field observations led to the following findings:-

1. Most of the Royal Tombs in the Valley of the Kings were excavated into the marls of the middle and lower part of Member I.

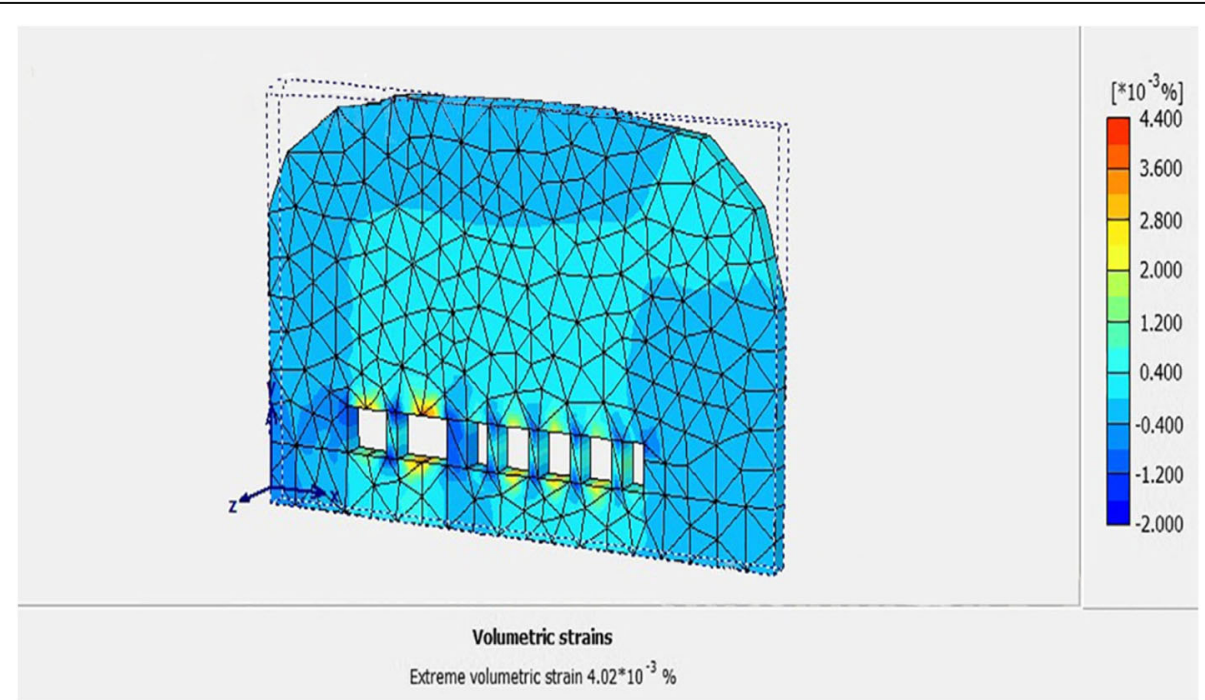

Fig. 24 Volumetric strains of the support rock pillars in Chamber 3. PLAXIS 3D 


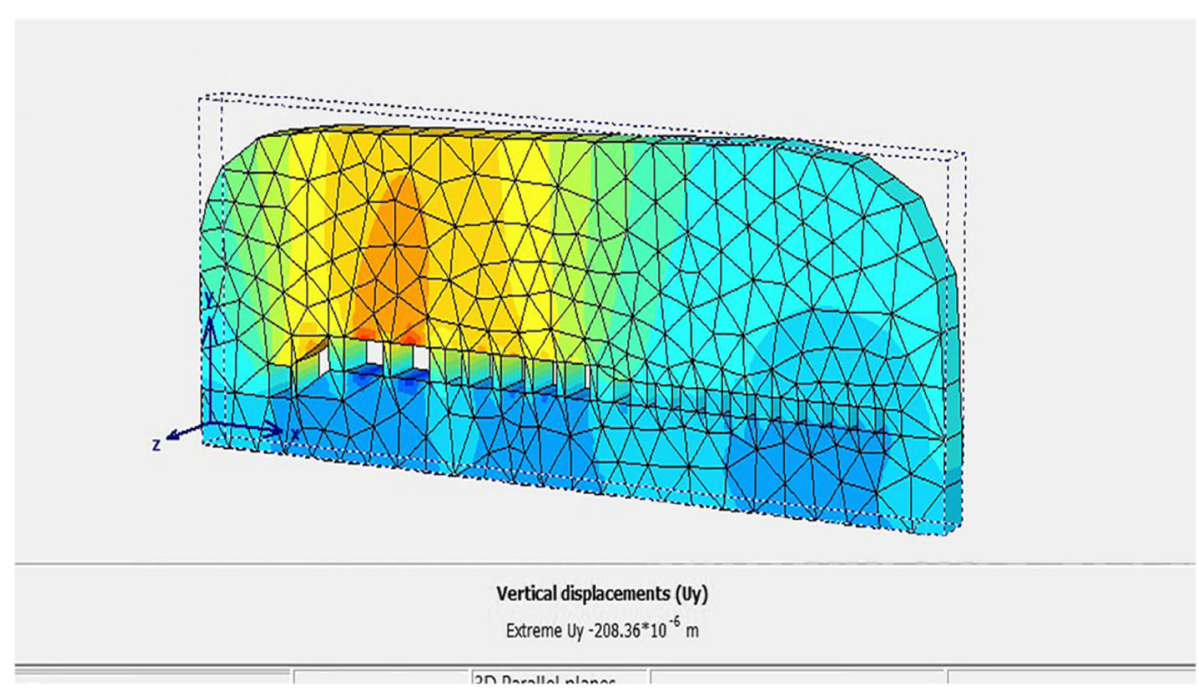

Fig. 25 Vertical displacement of rock pillars in Chamber 3and others small burial chambers

2. Presence of swelling-type clay minerals (Montmorillonite) in some rocks of the Thebes

Formation but, more importantly, in the underlying rocks of Esna formation. (Clay layers swelling).

3. The index properties show that the shale layers are medium expansive.

4. Anhydrite found in abundant quantities in the Esna Shale, may be a factor contributing to swelling of the Esna Shale.

5. Rock slope deformations (spreading) of the Thebes limestone blocks caused by volume changes in the underlying Esna shale, as shown in Fig. 6.

6. The lowermost unit of the Thebes Formation. However, KV5 penetrate into the underlying interbedded shale and marls of the Esna Formation. All of them show severe, irreversible rock structure deterioration originating from swelling and shrinkage. Water and debris from the past and recent flash floods had major impacts on wall decoration of the uppermost chambers and on pillars and wall structure in the chambers 1,2 and

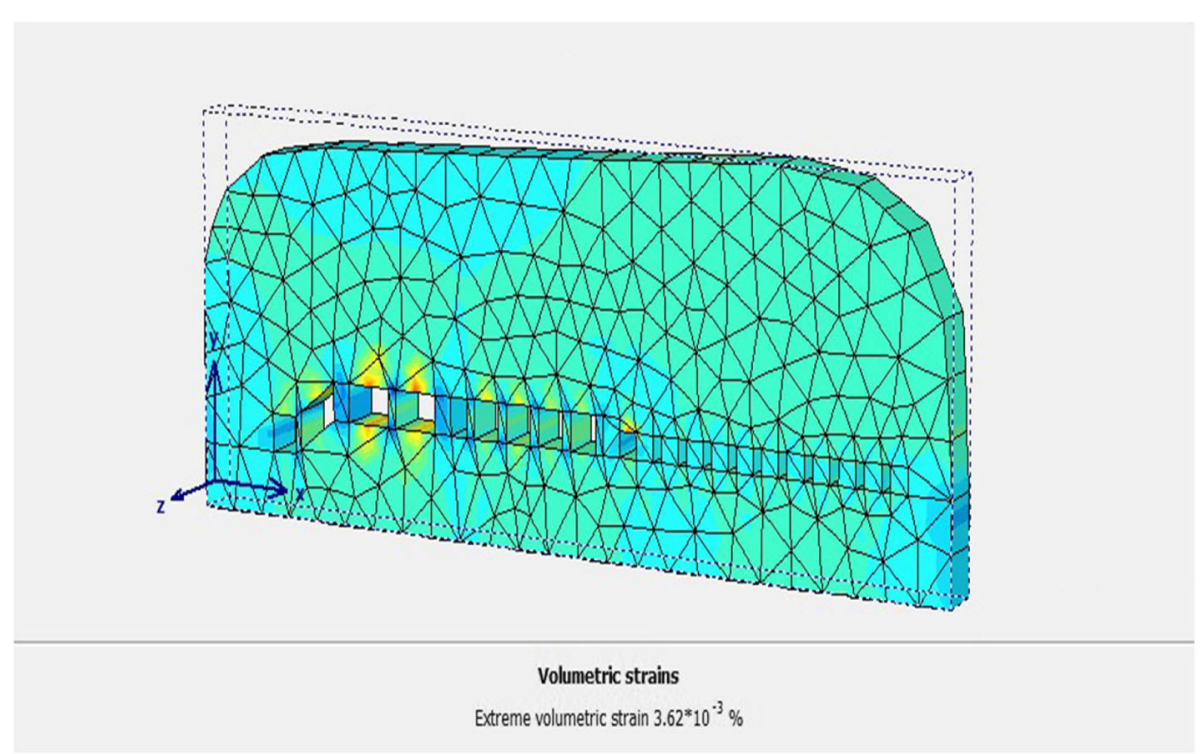

Fig. 26 Volumetric strains of rock pillars in Chamber 3and others small burial chambers 


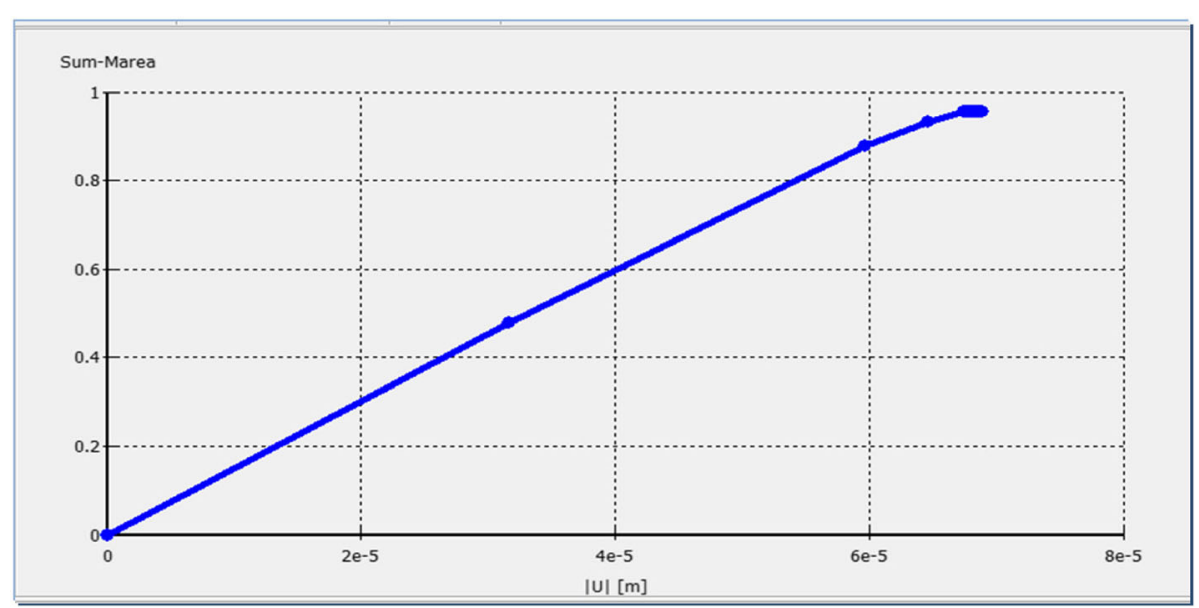

Fig. 27 Displacement progressive curve for the supported rock pillars in KV5

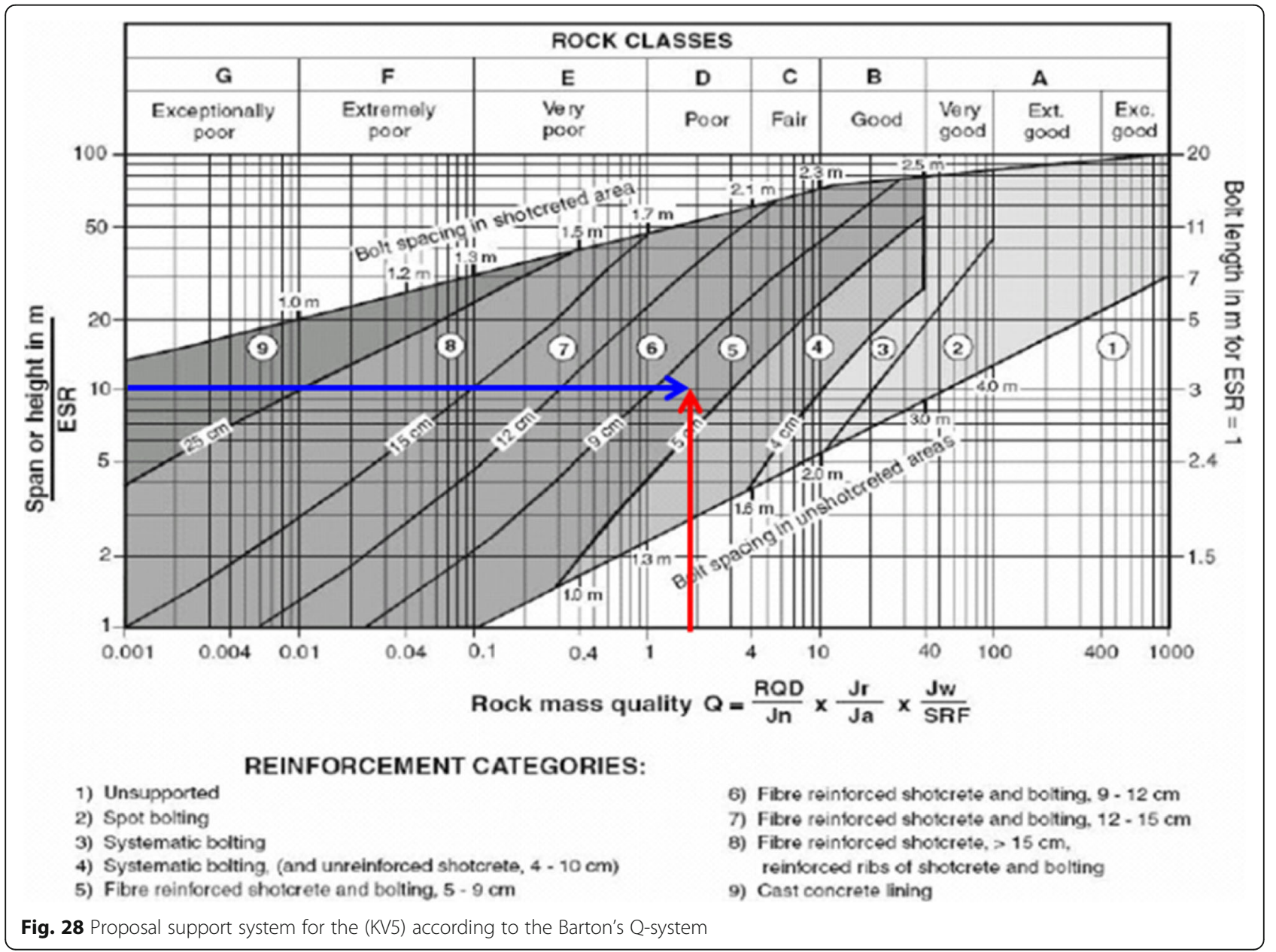




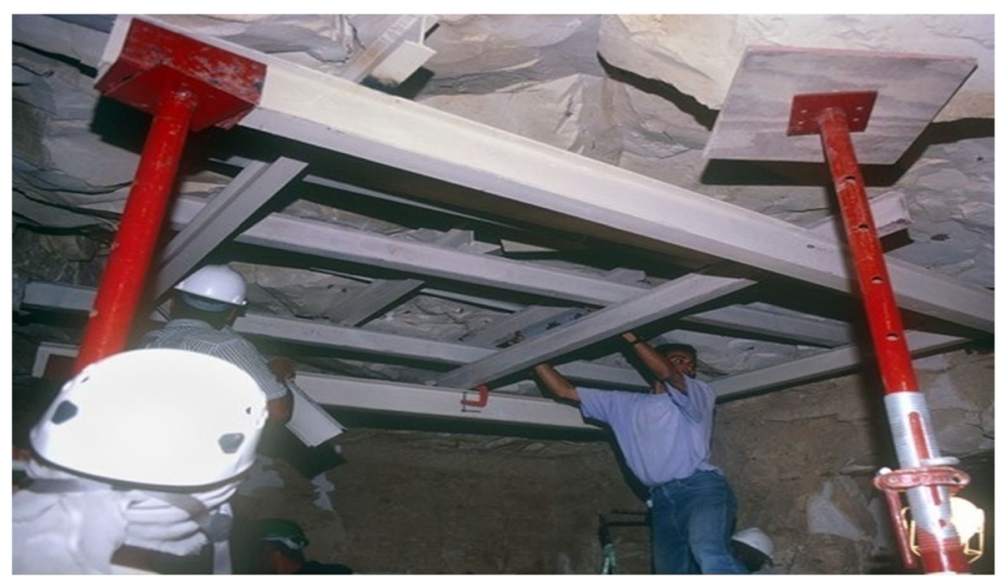

Fig. 29 Temporarily support system for the KV5, installed recently by the Theban Mapping Project. After TMP. Permission was granted by Weeks, K.R. (C) Theban Mapping Project 2006 to reuse this figure.

3. Historic flooding since the discovery of the tomb has caused major destruction of walls and pillars by repeated swelling and shrinkage of the shale. Moreover, accelerated humidity changes over the past 100 years have contributed to increasing deterioration of the rock structure.

7. The removal of shake units preceding the tomb uncovering brought about copious shake joints, which can be re-actuated amid quakes or other quick pressure discharges, for example, by swelling of the shale. At the point when water enters the tombs, it comes into contact with the shale at the lower chambers, and causes swelling, splitting and auxiliary disappointments in the floors, dividers, and columns.
8. Gravity rock falls and sliding of rock features along inclined discontinuities at the surrounding area.

9. Extensive jointing (rock discontinuities) present in the rock at tomb depth.

10. The overloading of geostatic loading due to the overburden strata on the supporting rock pillars is obvious and it induced critical vertical cracks in these pillars also some sections have an overriding influence on the pillar stability, particularly in terms of long-term creep effects and associated strength loss or thinning-out of the effective load bearing pillars and section, as shown in Fig. 35.

11. Rock detachment and falls from the ceiling, as shown in Fig. 9.

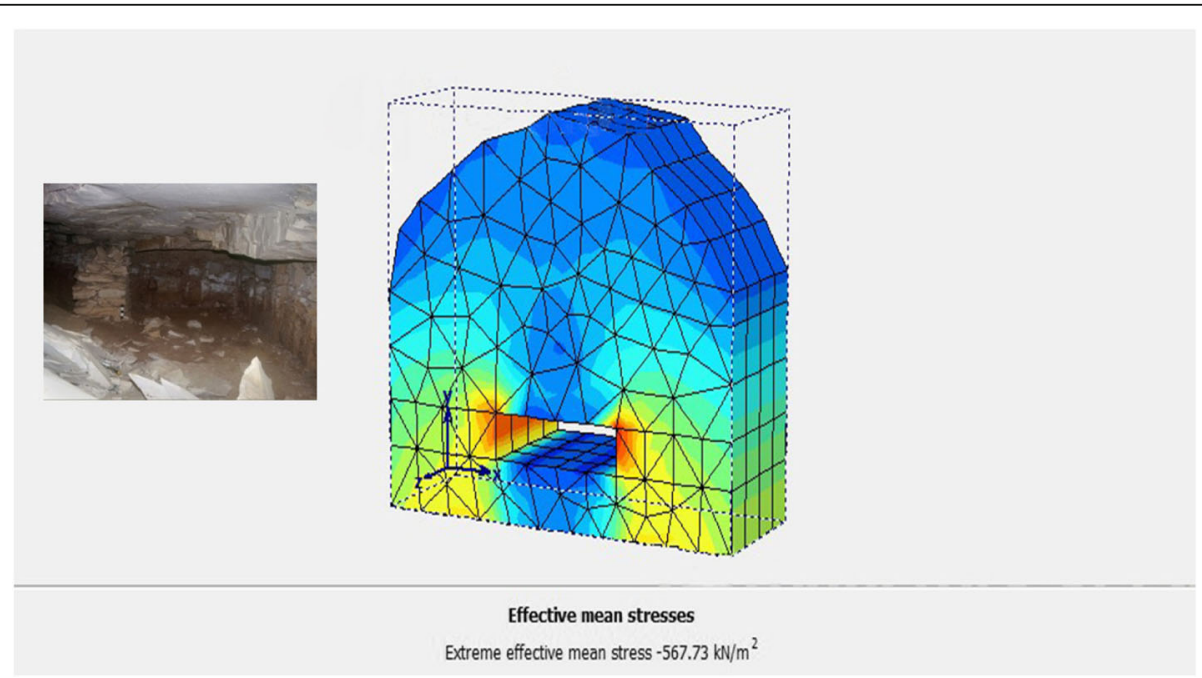

Fig. 30 Effective mean stresses in the ceiling and sidewalls of northern Chamber. PLAXIS 3D 


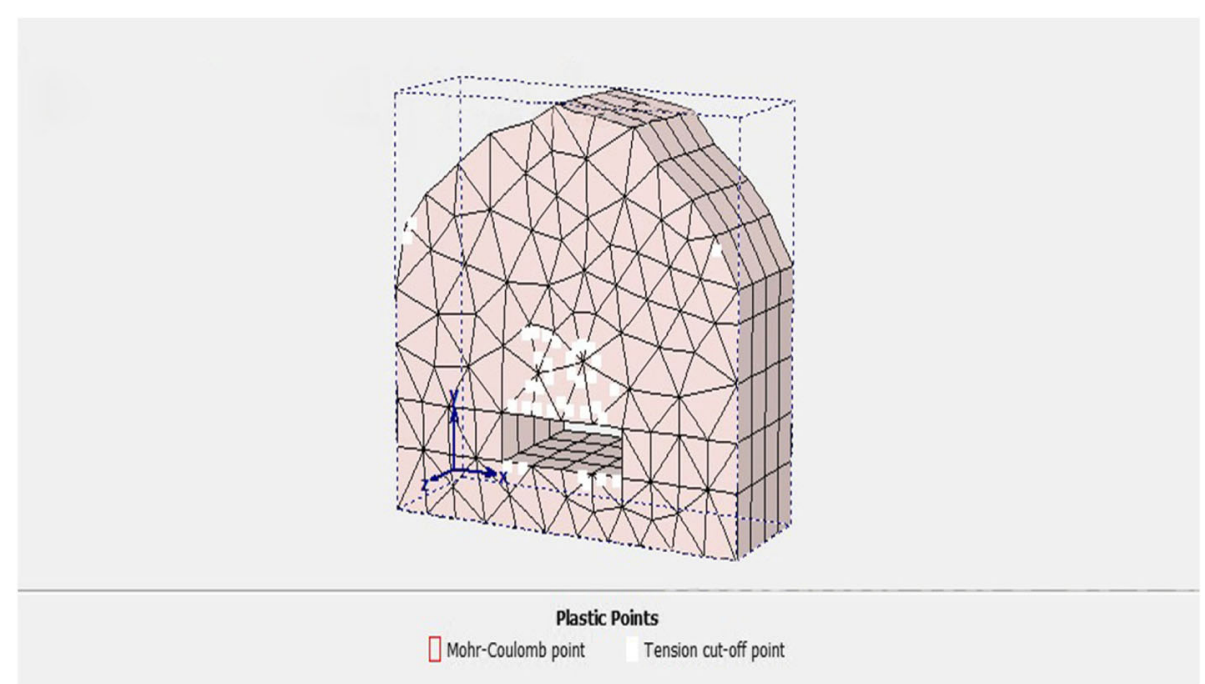

Fig. 31 Plastic Points in the ceiling and sidewalls of northern Chamber. PLAXIS 3D

12. Shape and measures deformation of the tombs or some sections of them.

13. Detachment and falls of renders with its wall paintings.

14. Intensive weathering and erosion of lower parts of the structural elements in particularly the supporting rock pillars in Chamber 3. The main structural deficiency attributed to the impact of flash floods in the past and few years ago, as shown in Fig. 8.

15. Physical, mechanical and chemical changes in the construction materials. The strength reduction is obvious and the UCS reached in some critical sections and supporting rock pillars to less than $1 \mathrm{MPa}$. Those secondary fossils content, due basically on shells about foraminifers and a portion mollusks, provide for climb on structural heterogeneity, which reflected in the variability of the mechanical properties What's more in the poor reproducible of the test results (Bukovansky et al. 1997).

16. Nearness of extensive, vertical, open cracks at the surface of slopes on the two sides of the valley. These breaks can be followed both in the valley parcels where the tombs are found. The cracks are effortlessly obvious in the greater part of the

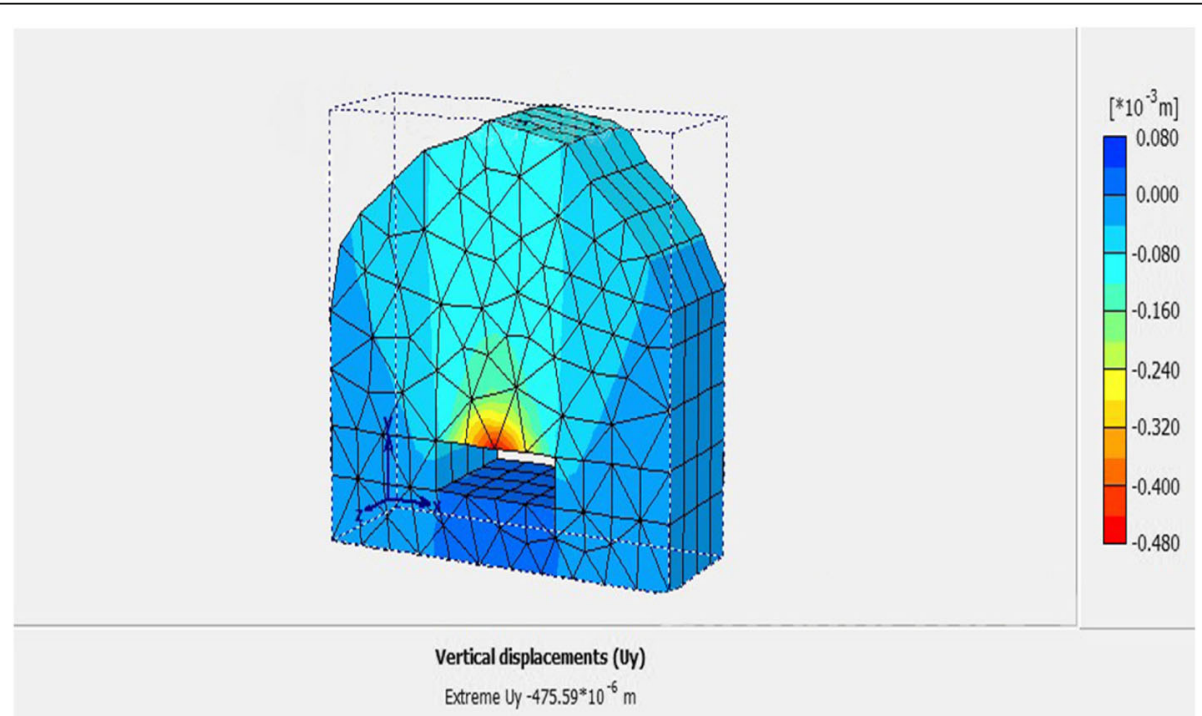

Fig. 32 Vertical displacement of the ceiling and sidewalls of northern Chamber. PLAXIS 3D 


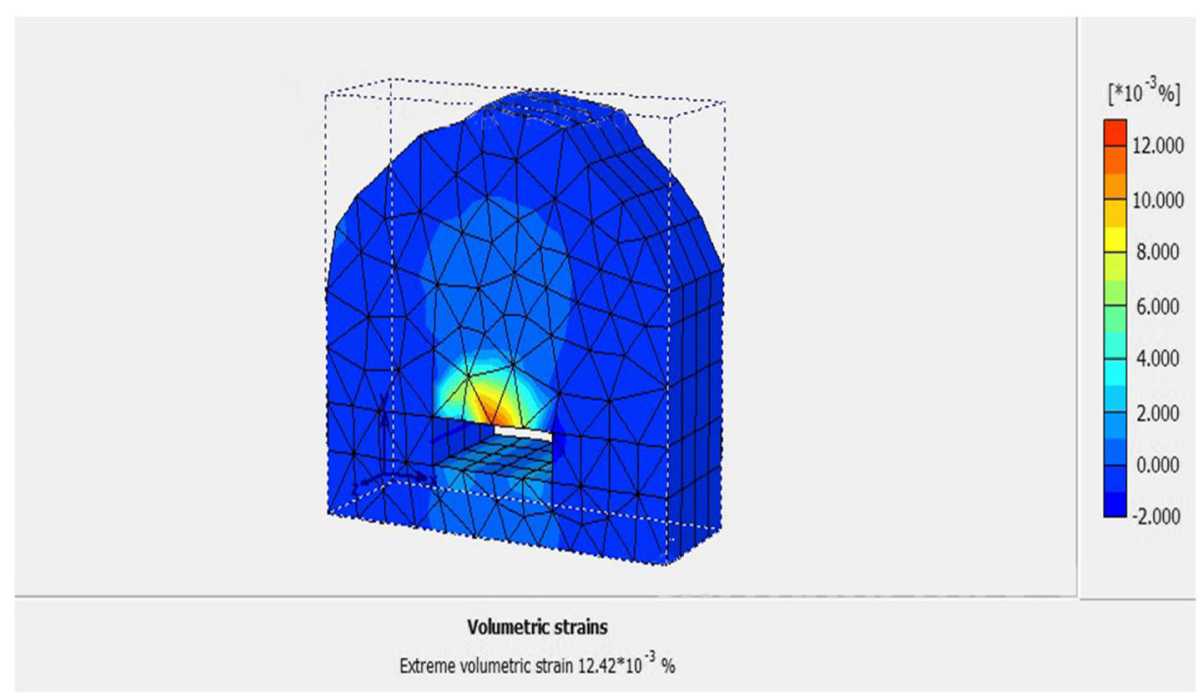

Fig. 33 Volumetric strains of the ceiling and sidewalls of northern Chamber. PLAXIS 3D

region. The beginning of these cracks has never been deciphered, albeit a few geologists viewed them as issues.

17. The numerical analysis results indicated that the safety factor of the structural support rock pillars in chamber 3 is very low in order of 1.37 and the overstress state is $1.28 \mathrm{MPa}$.

Remedial and retrofitting policies and techniques, static monitoring and control systems which are necessary for the strengthening and stability enhancement of the tomb, where the rock mass classification indicated the rock mass where the KV5 is excavated is poor rock, with RMR 39 and $\mathrm{Q}$ value 1.87.

Systematic bolts with 4-5 m long, spaced 1-1.5 m in Crown and walls with wiremesh.100-150 $\mathrm{mm}$ in Crown and $100 \mathrm{~mm}$ insides with Light to medium ribs Spaced $1.5 \mathrm{~m}$ where required for strengthening retrofitting of the KV5. Also it is recommended to use Fiber Reinforced Shotcrete and bolting 5-9 cm. Length of rock bolts $\mathrm{L}=2+(0.15 \mathrm{~B} / \mathrm{ESR})$ and

Table 5 Rock Tunneling quality index, Q-system determined as follow

\begin{tabular}{lll}
\hline Parameter & Description & Value \\
\hline RQD & Rock Quality Designation & 50 \\
$\mathrm{Jn}$ & Joint Number & 4 \\
$\mathrm{Jr}$ & Joint Roughness & 3 \\
$\mathrm{Ja}$ & Joint Alteration & 1 \\
$\mathrm{JW}$ & Joint Water Reduction Factor & 1 \\
SRF & Stress Reduction Factor & 1.13 \\
Total Q-System & & 1.87 Poor rock \\
\hline
\end{tabular}

maximum $\operatorname{span}$ (unsupported) $=2$ ESR $\mathrm{X} \quad \mathrm{Q}^{04}$; also nowadays we can use the advanced or nano carbon tubes because of its advanced physical and mechanical properties in particularly the compressive and shear strength. The third proposal is the installation of rock bolts with $4-9 \mathrm{~cm}$ and prestressed anchors or micro piles with $100 \mathrm{~mm}$ Diameter for the permanent support system for the rock pillars and sidewalls of the KV5.

\section{Conclusions}

We can state that most of what we can call now geotechnical problems was faced in the Valley of Kings where most of the large important subterranean decorated tombs of the pharaohs like sons of Ramses II tomb KV5 are found. This case study illustrates how the quantification of various variables permits an understanding of the problems facing a site and also suggests possible solutions.

In conclusion the detailed engineering analysis of the sons of Ramses II tomb KV5 at Luxor, Egypt proved that these unique monuments present low safety factors of the rock pillars which are structurally damaged, where the factor of safety F.S is about 1.37, (note that the acceptable safety factor for the underground structures is $>1.6$ in static state). Also the overstress state of the surrounding rocks is beyond the elastic regime (limit of domain), and all the rock pillars structural supports are subjected to high vertical compressive stresses. Many instability problems for static and dynamic loading were recorded and analyzed. Consequently a well-focused strengthening and retrofitting program is deemed necessary. 


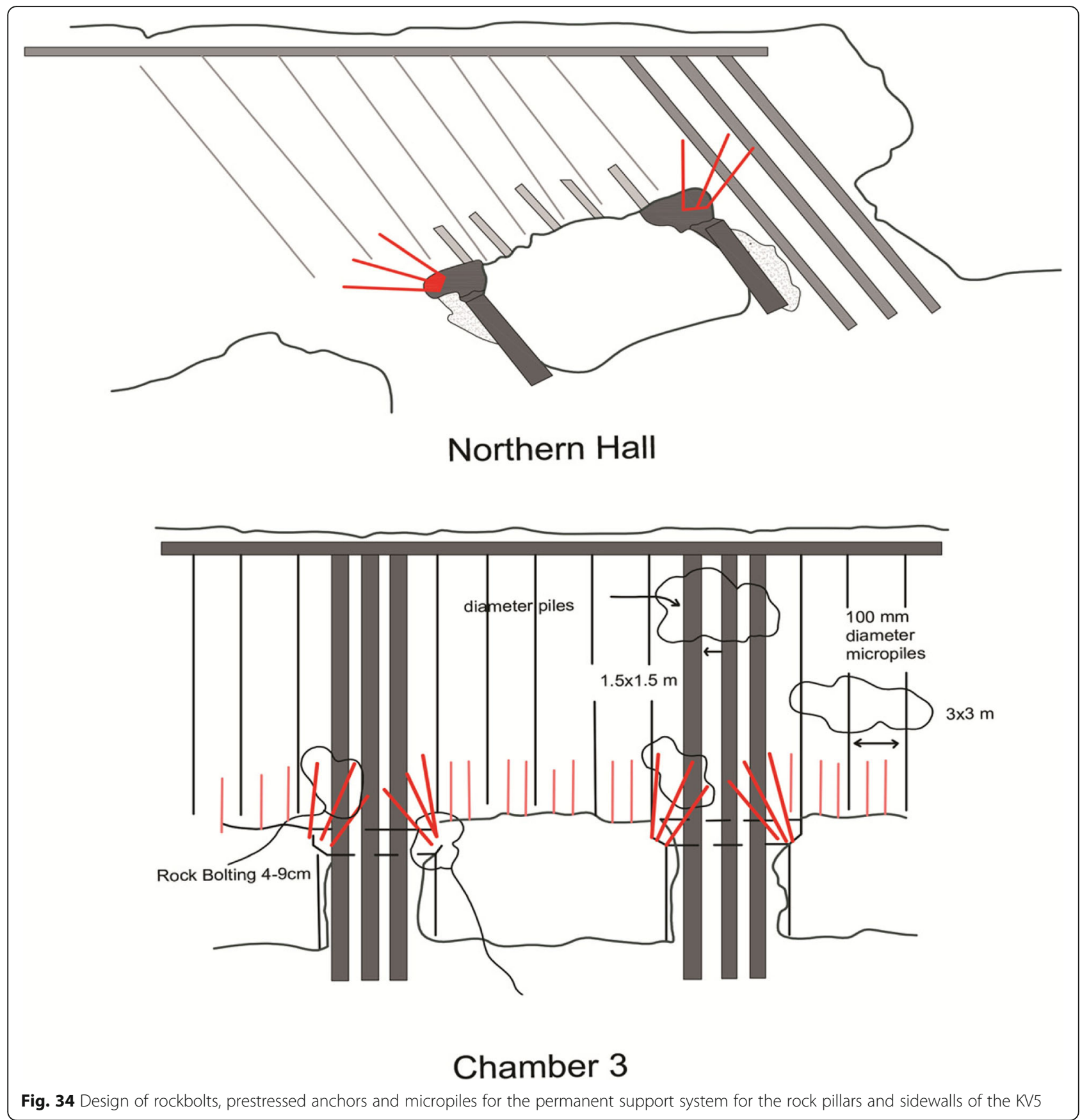



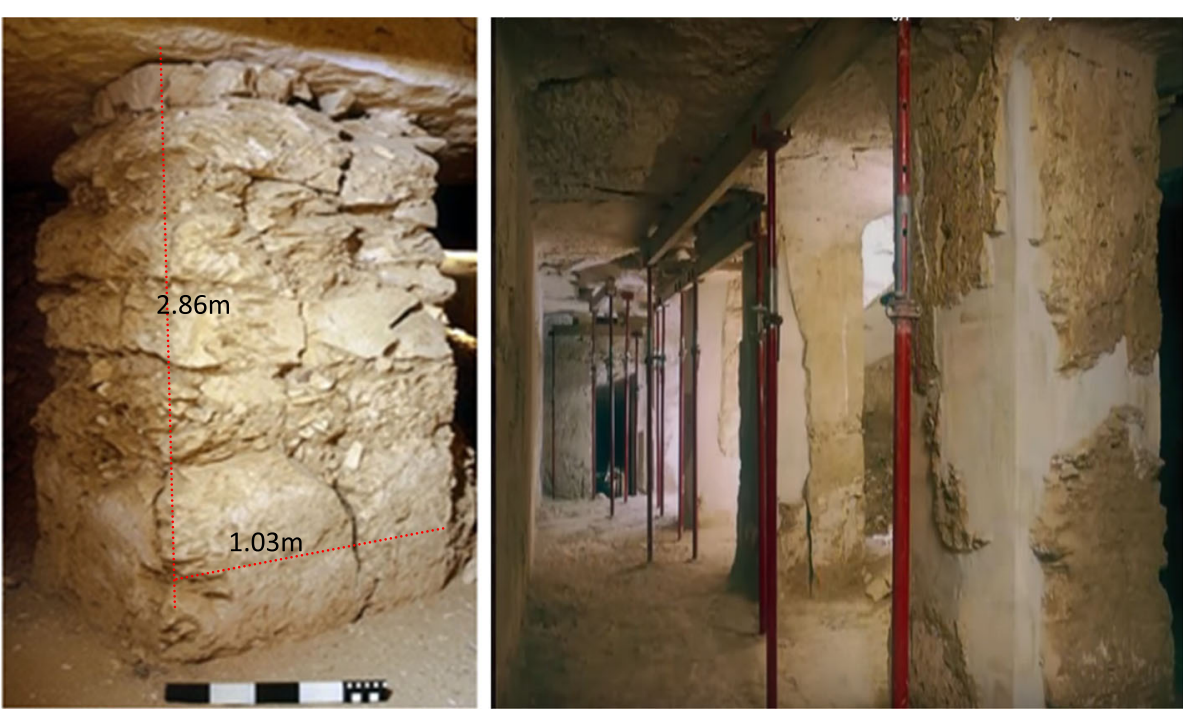

Fig. 35 Present state of the sixteen supporting rock pillars in the Chamber 3. which are structurally damaged. Vertical cracks due to the overloading and strength regression are obvious (http://www.thebanmappingproject.com/). Permission was granted by Weeks, K.R. @ Theban Mapping Project 2006 to reuse this figure

\section{Abbreviations}

Ja: Joint alteration number; JCS: Joint compressive strength; Jn: Joint set number; Jr.: Joint roughness number; JRC: Joint roughness coefficient; JW: Joint water reduction factor; Q: Rock mass quality; RMR: Rock mass rating; RQD: Rock mass designation; SRF: Stress reduction factor

\section{Symbols}

Aj: Joint area; At: is the area supported by the pillar; b u: Shear displacement; c: Cohesion between block joints; Ds: Rib spacing; Ei: Modulus of elasticity of intact rock; hcrit: is the minimum height of the cubical specimen of pillar material such that an increase in the specimen dimension will produce no further reduction in strength; Lcp: Reaction length; M D: Bending moment at yield limit; $\mathrm{M}$ p: Bending moment at plastic limit; $N$ p: Normal force at failure; Po: In situ stress; Qcf: Shear force; Qp: Shear force at failure; qu: is the UCS strength of the pillar material on cylinders with height (h) equal to twice the diameter; $\mathrm{U}$ : The shear displacement at each step of loading; $\mathrm{W}$ and $\mathrm{H}$ : are the width and height of the pillar respectively; $x \mathrm{~T}$ : Shear stress in resin annulus; a: Decay coefficient 1/in which depends on the stiffness of the system; Ap: is the area of the pillar; $\beta$ : Angle between the normal to the fracture plane and the horizontal plane; $\beta$ : Reduction coefficient of dilation angle; v: Poison ration of rock mass; $\sigma$ b: Applied stress; $\sigma$ c: Uniaxial compressive strength of rock; $\sigma \mathrm{n}$ : Normal force; $\sigma \mathrm{p}$ : is the strength of the pillar, $\sigma \mathrm{V}$ : is the vertical stress at the level of the roof of the excavation (KV5); $\varphi$ b: basic joint friction angle; $\varphi$ : Friction angle of the fracture

\section{Funding}

The author confirms that he is not currently in receipt of any research funding relating to the research presented in this manuscript.

\section{Availability of data and materials}

Data sharing not applicable to this article as no datasets were generated or analyzed during the current study.

\section{Author's contribution}

The whole database construction and analysis are presented in the manuscript had been achieved by the author. The author read and approved the submitted manuscript.

\section{Competing interests}

The author declares that he/she has no competing interests.

\section{Publisher's Note}

Springer Nature remains neutral with regard to jurisdictional claims in published maps and institutional affiliations.

Received: 9 November 2017 Accepted: 27 May 2018 Published online: 22 August 2018

\section{References}

Aubry, M.P., W.A. Berggren, C. Dupuis, E. Poorvin, H. Ghaly, D. Ward, C. King, R.O.'.B. Knox, K. Ouda, M. Youssef, and W.F. Galal. 2008. 2015 TIGA: a geoarcheological project in the theban necropolis. In Proceedings of the X International Congress of Egyptologists, Rhodes. luxor, Egypt: West Bank.

Barton, N.R. 1988. Rock mass classification and tunnel reinforcement selection using the Q-system. In Rock classification system for engineering purposes: ASTM special technical publication 984.1. ASTM International, ed. L. Kirkaldie, $59-88$

Barton, N.R., R. Lien, and J. Lunda. 1974. Engineering classification of rock masses for the design of tunnel support. Rock mechanics and rock engineering, Springer. 6 (4): 189-236.

Bieniawski, Z.T. 1989. Engineering rock mass classifications. New York: John Wiley and Sons.

Brown, E.T. 2012. Risk assessment and management in underground rock engineering -An overview. Journal of Rock Mechanics and Geotechnical Engineering 4 (3): 193-204.

Bukovansky, M., D.P. Richard, and K.R. Week. 1997. Influence of slope deformations on the tombs in the valley of the kings, Egypt. Proceedings of an International Symposium on Engineering Geology and the Environment 3: 3077-3080.

Clayton, P.A. 1995. "The Tomb of Sons of Ramesses II Discovered?" Minerva: International Review of Ancient Art and. Archaeology 6 (4): 12-15.

Deere, D.U. and Varde, O.A. 1990. "General report, engineering geological problems related to foundations and excavations in weak rocks," Proceedings of the 5th International Association of Engineering Geology Congress, Vol. 4, pp. 2503-2518.

Dunn, J. 2014. The geography and geology of the valley of the kings on the West Bank at Thebes. London.

Examine 2D. (2018). v.8.0 Program from Rocscience (2D stress analysis for underground excavations software). http://www.cesdb.com. Examine 2d. Hemeda, S. 2008. An integrated approach for the pathology assessment and protection of underground monuments in seismic regions. Application on 
some Greek-Roman monuments in Alexandria, Egypt. Ph. D Thesis, Civil Engineering Department, Aristotle University of Thessaloniki, Greece.

Hemeda, S., Pitilakis, K., Bakasis, E. (2010) Three-Dimensional Stability Analysis of the Central Rotunda of the Catacombs of Kom El-Shogafa, Alexandria, Egypt. $5^{\text {th }}$ international conference in geotechnical earthquake engineering and soil dynamics, May 24-29 2010, San Diego, California, USA.

Hemeda, S., and K. Pitlakis. 2010. Serapeum temple and the ancient annex daughter library in Alexandria, Egypt: Geotechnical-geophysical investigations and stability analysis under static and seismic conditions. Engineering Geology 113: 33-43.

Litherland, P. 2013. Landscape and human activity in the valley of the kings: seriation, Geology, Construction techniques and their implications in the XVIIITH Dynasty" Master Thesis, Cambridge University.

PLAXIS 3D SOFTWARE. (2018). INFO@ www.PLAXIS.COM.

Reeves, N., and R. Wilkinson. 1966. Complete valley of the kings, The (tombs and treasures of Egypt's greatest pharaohs). Thames and Hudson Itd.

RocLab 1.0. (2018). Software program for determing rock mass strength from Rocscience.

Salamon, M.D.G., and A.H. Munro. 1967. A study of the strength of coal pillars. Journal of the Southern African Institute of Mining and Metallurgy 68 (2): 55-67 September.

Siliotti, A. 1997. Guide to the valley of the kings. Barnes \& Noble Books.

Weeks, K.R. 1994. The Theban Mapping Project: Report of the 1994 Field Season. Cairo: Theban Mapping Project.

Weeks, K.R. 1995. The Work of the Theban Mapping Project and the Protection of the Valley of the Kings. In Valley of the Sun Kings: New Expeditions in the Tombs of the Pharaohs, ed. R. Wilkinson. Tucson: University of Arizona Egyptian Expedition.

Weeks, K.R. 1998. The lost tomb. New York: William Morrow and Company Weeks, K.R. 2000. Atlas of the valley of the kings. Publications of the Theban mapping project. Cairo: American University in Cairo Press.

Weeks, K.R. 2006. KV5: A preliminary report on the excavation of the tomb of the sons of Ramesses II in the valley of the kings. The American University in Cairo Press.

Weeks, K.R. 1992. The Theban Mapping Project and Work in KV 5. In After Tut'ankhamun: Research and Excavation in the Royal Necropolis at Thebes, ed. Carl Nicholas Reeves, 99-121. London: Kegan Paul International.

Wüst, R., and J. McLane. 2000. Rock deterioration in the Royal Tomb of Seti I, valley of the kings, Luxor, Egypt. Engineering Geology 58: 163-190.

\section{Submit your manuscript to a SpringerOpen ${ }^{\circ}$ journal and benefit from:}

- Convenient online submission

- Rigorous peer review

- Open access: articles freely available online

- High visibility within the field

- Retaining the copyright to your article 